\title{
How costly is corporate bankruptcy for top executives?*
}

\author{
B. Espen Eckbo \\ Tuck School of Business at Dartmouth \\ b.espen.eckbo@dartmouth.edu \\ Karin S. Thorburn \\ Norwegian School of Economics \\ karin.thorburn@nhh.no \\ Wei Wang \\ Queen's School of Business \\ wwang@business.queensu.ca
}

November 15, 2011

Preliminary - do not distribute without permission

\begin{abstract}
We provide large-sample estimates of CEO personal bankruptcy costs that, for the first time, account for the CEO's post-bankruptcy employment income. We track CEO employment changes using 342 U.S. public companies filing for Chapter 11 between 1995 and 2008. Surprisingly, one-half of the incumbent CEOs maintain full-time employment - in sharp contrasts with the zero reemployment rate traditionally assumed in the literature. Two-thirds are hired by a new company, and several continue as top executives. Also surprising, the median total compensation change from the new employment is close to zero, suggesting that the CEO is not "tainted" by the bankruptcy event. The other half of the incumbent CEOs, who do not maintain full-time employment, experience an income loss with a median present value of $\$ 4$ million (discounted until retirement age). This implies an ex ante expected median personal bankruptcy cost of $\$ 2$ million (in constant 2009 dollars). We also provide some first evidence on how creditor activism, in particular through debtor-in-possession (DIP) financing, affects expected CEO personal bankruptcy costs.
\end{abstract}

\footnotetext{
${ }^{*}$ We thank our team of research assistants at Dartmouth College and at Queen's University: Xiaoya Ding, Milton Fung, Sam Guo, Matt Murphy, Sammy Singh, Lauren Willoughby, Yuao Wu, and Hank Yang. We are also grateful for partial financial support for this project from Tuck's Lindenauer Center for Corporate Governance, from SNF project "Krise, omstilling og vekst", and from Queen's School of Business Research Program.
} 


\section{Introduction}

High personal costs of financial distress give managers incentives to hedge against default by reducing leverage, choosing less risky investments, and managing their firms more efficiently. Designing labor contracts which regulate these incentives is not only difficult in theory (Berk, Stanton, and Zechner, 2010), it requires empirical evidence which is largely missing in the literature. A major empirical obstacle has been to track the departed executive's new employment (if any), which is needed to estimate loss of managerial rents. Thus, despite a substantial literature on managerial turnover, systematic empirical evidence on the personal cost of forced turnover is sparse.

Gilson (1989) and Gilson and Vetsuypens (1993), the studies on U.S. bankruptcies closest in spirit to ours, present evidence suggestive of significant managerial income loss from bankruptcy. For example, top executives on average lose $\$ 1.3$ million in present value of future income to retirement age. Moreover, new (replacement) CEOs hired from the outside receive significantly greater compensation than the outgoing $\mathrm{CEO}$, while the compensation is significantly lower if the new CEO is promoted internally. These findings are interesting as they suggest that the departing CEO earned rents before being "tainted" by financial distress and bankruptcy.

The contribution of our paper to this literature is twofold. Fist and foremost, we identify the old CEO's post-departure employment, which in turn allows us to estimate the post-departure employment income. Thus we are able to relax the strong assumption in the literature that the post-departure CEO income is zero until retirement. This turns out to be important as we find that as much as two-thirds of the former CEOs receive some kind of new employment starting on average one year after departure. Of the CEOs receiving new employment, the majority get full-time employment, and a significant portion move to become CEO of a new company. This rate of success in regaining full employment is surprising by any standard - especially given that our departing CEOs were tainted by severe financial distress and even default. Thus, a precise estimate of the executives' personal cost of bankruptcy requires one to offset the initial income loss of the departing CEO with the present value of the new employment income stream, which is what we do.

Our second main contribution is to investigate the role of creditor control rights and associated "creditor activism" in affecting CEO personal bankruptcy costs. Much has been written about the 
increased efficiency of Chapter 11 proceedings over the past two decades-largely a reflection of the emergence of market-driven creditor control strategies during the bankruptcy and restructuring process (Baird and Rasmussen, 2002; Ayotte and Morrison, 2009; Jiang, Li, and Wang, 2011). Examples of such activism include loan to own (acquisition) strategies, prepackaged filings (sometimes with a merger agreement in place), debtor-in-possession (DIP) financing, and rapid sale of the firm inside Chapter $11 .^{1}$

While this increased use of creditor control mechanisms undoubtedly has lowered corporate bankruptcy costs, the focus here is whether it has also impacted CEO personal bankruptcy costs. Since top executives exercise "residual" control rights (rights not actively exercised by securityholders) it is natural to expect creditors to take an active interest in which CEO to replace - and with whom. This interest is driven not only by the objective of retaining or hiring high-quality CEOs, but also to regulate CEO implementation of risk-shifting strategies on behalf of residual claimants (Jensen and Meckling, 1976). Also, CEOs with different risk aversion and career concerns may implement different investment policies, which in turn affect expected creditor recovery rates (Gibbons and Murphy, 1992; Hirshleifer and Thakor, 1992; Zwiebel, 1995; Eckbo and Thorburn, 2003). Yet another concern may be to maintain good, ongoing supplier relationship developed by the firm's exisiting executives which may be difficult for an outsider to recreate. ${ }^{2}$ Finally, CEO investment choices leading up to and during bankruptcy are also influenced by legal fiduciary responsibilities, which expand to include creditors when a company becomes insolvent (Gilson, 1990; Gilson and Vetsuypens, 1994; Branch, 2000; Ayotte and Morrison, 2009).

We measure creditor control rights using debt characteristics such as the filing firm's prefiling debt structure (leverage ratio, presence of large bank loans), filing form (prepack), and DIP financing. Of these, we expect DIP financing to be the most effective, as it allows the creditor to write financing restrictions directly into the debt contact, a suspicion which is supported by our evidence. $^{3}$ While the use of DIP financing has been thoroughly documented elsewhere (Dahiya,

\footnotetext{
${ }^{1}$ Creditor activism was not always accepted by the courts. To illustrate, in the bankruptcy of Sunbeam Oster in the early 1990s, Japonica Partners, led by Paul Kazarian, purchased debt claims to influence the bankruptcy outcome - much as is commonplace today. However, the court reacted to this investment by refusing to let Kazarian vote his debt claims under the theory that he effectively was a "shareholder in waiting". See also Hotchkiss, John, Mooradian, and Thorburn (2008) for a review of evidence on creditor involvement in the bankruptcy process.

${ }^{2}$ An example of this is the 2007 bankruptcy filing by Hancock Fabrics Inc., where the company's suppliers formed an unsecured creditor committee and made sure the prefiling CEO Jane Aggers stayed on both through bankruptcy and thereafter.

${ }^{3}$ To illustrate the power of DIP financing: In Recoton's 2003 bankruptcy filing, senior creditors replaced the old
} 
John, Puri, and Ramirez, 2003), it was not yet available during the early sample period of Gilson and Vetsuypens (1993), and so we are the first to investigate whether this and other creditor control mechanisms impact CEO turnover and compensation changes in bankruptcy.

Our sample consists of 342 large public U.S. companies that filed for Chapter 11 after 1995 and before 2008, and where the case was resolved before early 2011. We track CEO turnover from three years prior to filing until three years after emerging from Chapter 11 (or until liquidation) — a total of 2,197 firm-year observations through 2010. This sample is the largest in the bankruptcy turnover and compensation literature and large also by the standards of the broader turnover literature. ${ }^{4}$

We report turnover statistics which, as expected, are much higher than the turnover rate provided in studies of solvent firms. ${ }^{5}$ Of the original CEOs employed by the firm three years prior to the filing year, $81 \%$ have departed by the end of year +2 (where year 0 is the year of bankruptcy filing). In comparison, with a sample of 126 firms in financial distress, 1979-1984, Gilson (1989) reports that $66 \%$ of incumbent CEOs remain in office two years following the year of out-of-court restructuring or Chapter 11 filing. ${ }^{6}$ We also document that about half of the departing CEOs were forced to leave, at an average age of 54 and with a five-year tenure as CEO. Interestingly, when a CEO is forced out, it is most often by active creditors.

For each CEO, we record the severance pay (which has a median of $\$ 1.6$ mill.), ${ }^{7}$ the type of new employment, and estimate the compensation change (salary, bonus and stock-based grants). The CEO's severance pay and new employment compensation is estimated using information from 10-Ks, proxy statements, Factiva, ExecuComp, CEO compensation in public firms matched on firm size and industry, and private-firm compensation discounts recently reported by Gao, Lemmon, and Li (2011). They use compensation information on private firms in Capital IQ and estimate that total CEO compensation in private firms is 30\% lower than CEO compensation in public firms.

CEO and appointed Jerry Kalov from the outside, and then provided debtor-in-possession (DIP) financing with a covenant stating that removal of Kalov would be considered a default event on the DIP facility.

${ }^{4}$ To our knowledge, the only other large-sample study tracking CEO income changes around bankruptcy filings is Eckbo and Thorburn (2003) who study 265 bankruptcy auctions in Sweden. We return to their evidence below.

${ }^{5}$ For recent studies of CEO turnover outside of bankruptcy, see e.g. Huson, Parrino, and Starks (2001), Huson, Malatesta, and Parrino (2004), Perez-Gonzales (2006), Evans, Nagarajan, and Schloetzer (2010), Kang and Mitnik (2010), and Jenter and Kanaan (2010).

${ }^{6}$ Gilson and Vetsuypens (1993), Betker (1995), Hotchkiss (1995), Khanna and Poulsen (1995), Evans, Luo, and Nagarajan (2008), Ayotte and Morrison (2009) and Jiang, Li, and Wang (2011) all report evidence on turnover rates around Chapter 11 filings.

${ }^{7}$ Fee and Hadlock (2004), Yermack (2006) and Goldman and Huang (2011) report similar severance payments for firms outside of bankruptcy. 
While we are able identify the CEO's actual new employment category, the new employment income must in most cases be estimated. The exception is when the CEO remains with the firm, or assumes a position as CEO of another public company, and the compensation information is available directly on ExecuComp. If, however, the CEO moves to a CEO position in a private company, we use the contemporaneous CEO pay recorded in ExecuComp for a public firm matched on size and industry, and then reduce this total pay by the average percentage discounts for CEOs in private companies reported by Gao, Lemmon, and Li (2011).

For new non-executive positions at either public or private firms, we again use size-matched firms from ExecuComp in combination with reported discounts for such positions. Only if there is no new employment or if the CEO retains an honorary position with the firm do we assume that the CEO income drops to zero. ${ }^{8}$ Thus, we are assigning a typical compensation to most of the departing CEOs, conditional on the true job category and firm size. By construction, this estimation technique rules out a "fire-sale" discount in the CEO's new compensation. This is unlikely to have much of an effect on our bankruptcy cost estimates for two reasons: First, there is little evidence of a fire-sale discount in the CEO compensation change in those cases where we $d o$ observe the new compensation directly. Second, a fire-sale discount in pay is bound to be temporary as the CEO rebuilds some of her reputation over time. Thus, the average pay level may in fact be the best estimate for most years until retirement. ${ }^{9}$

For the overall sample, the median percent CEO total income change is $-76 \%$. Discounted at $10 \%$ until retirement plus any separation received at departure yields a median estimate of about \$-2 million in constant 2009 dollars. This is our sample-wide estimate of CEO personal bankruptcy costs. This cost estimate does not include loss of the value of CEO (vested) share-holdings in the bankrupt firms, which fall from a median value of $\$ 12$ million in year -3 to zero in the year of bankruptcy filing. Thus, the median total CEO wealth loss is more than $\$ 14$ million.

In the total sample, one-half does not become fully employed again, and the other half receive a new full-time position (within (about) one year after departing from the firm). The former subsample has large, negative compensation changes, while the CEOs in the latter half receive a

\footnotetext{
${ }^{8}$ In this category we found evidence of retirement, death, back-to-school, jail, under investigation, etc.

${ }^{9} \mathrm{~A}$ measurement issue of a different type arises as the frequency distribution of CEO compensation change is highly skewed. We therefore follow Gilson and Vetsuypens (1993) and focus primarily on the median value. Estimates based on the mean tend to produce greater personal bankruptcy costs than estimates based on the median, whether we report percentage changes or dollar changes in total compensation.
} 
cushion in the form of significant new income. It is in this subsample where the extant estimates of personal bankruptcy costs make the greatest error by leaving out the positive effect of future employment income. We are particularly interested in the incumbent CEOs, i.e., CEOs in place at the very beginning of the bankruptcy event period). These are the CEOs who suffer potentially the most from being associated with the bankruptcy event, and so may have the greatest difficulty in finding high-value new employment. ${ }^{10}$

We find that approximately $50 \%$ incumbent CEOs find new full-time employment as chairman of the board, CEO, and non-CEO executives. When the compensation change is discounted to retirement age, and after adding any severance pay, the estimated personal bankruptcy cost for this group as a whole has a median value of $\$-0.2$ million, which is statistically indistinguishable from zero. Thus, this group as a whole suffers relatively modest personal bankruptcy costs, if any. This abstracts from the average loss of equity investment value, which is large (about $\$ 12$ million) but not a bona fide bankruptcy cost as defined here. In contrast, the incumbent CEOs who do not find new full-time employment suffer a mean percentage decline in compensation of $-89 \%$ with a median of $-100 \%$. The estimated median personal bankruptcy cost for this group is $\$-4$ million.

Another interesting finding is that CEOs who leave voluntarily suffer lower personal bankruptcy costs than CEOs who are forced out (typically by creditors). Leaving voluntarily for another fulltime employment opportunity leaves the CEO with a median personal bankruptcy cost of zero, while those who find new full-time employment after being forced out suffer a median personal bankruptcy cost of $\$-1.4$ million. A consistent explanation is that CEOs who earn rents prior to bankruptcy prefer to stay until they are forced out, and then take a pay-cut as the wage is being reset to a more competitive level in the new full-time employment opportunity.

In multivariate analysis we find variables related to CEO employment preference, power, and entrancement affect the probability of CEO being rehired and their personal income loss after departure. After applying the regression models to estimate the predicted probability of rehiring and expected income loss for all CEOs in our sample we find that the ex ante personal bankruptcy costs strongly predict the decision of CEO voluntary turnover. This finding complements previous studies on CEO forced turnover.

\footnotetext{
${ }^{10}$ Other CEOs who are hired (and possibly fired) during the bankruptcy event period include restructuring specialists which are not personally tainted by the bankruptcy event.
} 
The rest of the paper is organized as follows. Section 2 describes the sample selection procedure and describes CEO turnover during the bankruptcy filing event period. This section also provides a cross-sectional regression analysis of the determinants of CEO turnover, strongly confirming that creditor control through DIP financing increases the probability of forced turnover. Section 3 provides estimates of CEO personal bankruptcy costs and its cross-sectional determinants. The cross-sectional model for bankruptcy costs is also used to generate an expected CEO bankruptcy cost for each sample CEO, which in turn is used in a joint estimation of CEO turnover and compensation change. Section 4 concludes the paper. A full description of the variables used throughout the paper's analysis is found in Appendix 1.

\section{CEO turnover around bankruptcy}

\subsection{Sample selection}

Our sample selection starts with a list of all 497 Chapter 11 bankruptcy filings in the period 1996-2007 by US public firms with book assets above $\$ 100$ million in constant 1980 dollars from the Bankruptcy Research Database, provided by Professor Lynn LoPucki at UCLA Law School. The status of the cases are updated as of the beginning of 2011. We eliminate 18 dismissed or pending cases, leaving us with a total of 479 bankruptcy filings. These cases are matched with Compustat to obtain firm level financial information (described below). If any information is missing in Compustat, we manually collect the financial information from 10-Ks in Edgar.

We also require sample information on top executive personal characteristics, including name, title, directorship, chairmanship, age, gender, tenure, year of joining the firm, and annual compensation. This information, which is summarized below, is obtained primarily from the ExecuComp database. ExecuComp stops coverage of a firm when it delists from the stock exchange due to bankruptcy. For this reason, for three-quarters of the sample firm-years we manually collect information on the top executives from SEC filings, including proxy statements and 10-K forms through Edgar. Our sample requirement is for information on CEO personal characteristics and compensation to be available in the last fiscal year before Chapter 11 filing (the fiscal year ending within 12 months of filing). This eliminates another 137 firms, leaving a final sample of 342 bankrupt firms.

The 342 firms, which represent a total of 2,197 firm-year observations, is to our knowledge 
the largest and most comprehensive sample currently available in the bankruptcy turnover and compensation literature. Table 1 shows the annual frequency distribution of the sample firms' Chapter 11 filings. Roughly half of the firms filed for bankruptcy in the 2000-2002 period, with the the lowest number of filings occurring at the beginning and at the end of the sample period.

The table also shows the annual size (sales and assets) of the sample firms. The average firm has sales and assets of $\$ 2.9$ billion and $\$ 3.3$ billion, with a median of $\$ 0.7$ and $\$ 0.8$ billion, respectively, in the last fiscal year prior to filing. The bankruptcy proceedings last for 17 months on average (median 13 months), and 30\% of filings are prepackaged. Overall, the bankrupt firm emerges as an independent company in two-thirds of the cases, and are liquidated and acquired in $26 \%$ and $10 \%$ of the cases, respectively. There are no discernible trends in duration or outcome over the sample period.

The sample firms are distributed across a large number of 2-digit SIC industries. The four industries with the highest representation of bankrupt firms are SIC-49 Communications (47 cases or $14 \%$ of the sample firms), SIC-73 Business Services (17 cases or $5 \%$ of the sample), SIC-33 Primary Metals Industries (16 cases or 5\% of the sample), and SIC-80 Health Services (14 cases or $4 \%$ of the sample).

We also select a control sample of firms from the ExecuComp universe, after the removal of our sample firms. We require the matching firm to have the same 2-digit SIC code and the sales to be within $30 \%$ of the sales of our sample firm (i.e. the ratio of the sales of the matched firm and the sales of the bankrupt firm is between 0.70 and 1.30). This control sample is used below as a benchmark, for example, in gaging the decline in CEO compensation during bankruptcy restructuring.

\subsection{CEO turnover statistics}

CEO turnover is primarily identified from ExecuComp, proxy statements, and 10-Ks. For companies that delist and stop filing with the SEC after entering bankruptcy, we resort to bankruptcydata.com and Factiva news search to identify whether there is CEO turnover throughout the reorganization process.

Panel A of Table 2 shows CEO turnover by year relative to bankruptcy filing. We follow each sample firm starting three fiscal years prior to filing and, unless the firm is liquidated or acquired, ending three fiscal years after the bankruptcy case is resolved. The year of bankruptcy filing is 
denoted 0 . Most of the bankruptcy proceedings end in year 1 or 2, with a few cases continuing for up to six years. Thus, the last year in our sample is year 9. The 144 firm-year observations in years 4 through 9 are combined in the table on a single row labeled $4+$.

There are a total of 531 incidents of CEO turnover, corresponding to $24 \%$ of all firm-years in the sample. The highest turnover frequency is in year 1 (33\%), closely followed by year $2(30 \%)$ and year 0 (29\%). We lack information on the departing CEO in the first year that the firm enters our sample, ${ }^{11}$ leaving 474 CEO turnover incidents, for which we have information on the departing CEO.

Our turnover sample of 474 is large by the standards of the U.S. bankruptcy literature. For example, Gilson (1989) samples 176 turnover events (99 from financially distressed firms and 77 from non-distressed firms) and trace employment of 73 CEOs who depart from financially distressed firms. Gilson and Vetsuypens (1993) study 77 CEOs with $31 \%$ of the CEOs replaced. ${ }^{12}$ Betker (1995) covers 75 Chapter 11 filings. Hotchkiss (1995) traces cumulative turnover rate from two years before filing to emergence in a sample of 197 Chapter 11 filings. Khanna and Poulsen (1995) study 128 Chapter 11 firms, and Kang and Mitnik (2010) examine a total of 99 distressed firms. Jiang, Li, and Wang (2011) study a sample similar to ours, however, they do not trace CEO turnover either before bankruptcy filing or after the case resolution where a large proportion of the CEO turnover actually takes place in our data.

Column 5 of Panel A shows the distribution of the 474 departing CEOs across years -2 through liquidation/acquistion or three years after the resolution of bankruptcy. The average CEO is 54 years when leaving the firm and has served as CEO for a period of 5 years. As discussed further below, about half of the turnover is classified as "forced", with the highest fraction of forced turnover (61\%) in year 2 and the lowest $(32 \%)$ in year -2 . Of the original CEOs in place at the end of year $-3,56 \%$ have left at the end of the year of filing (year 0 ) and as many as $81 \%$ has left two years later.

We search 10-Ks and Factiva for the turnover reason for each of the 474 departed CEOs. Panel B of Table 2 presents the distribution of CEO turnover across different reasons. ${ }^{13}$ In 99 cases (21\%),

\footnotetext{
${ }^{11}$ This is the case for all 46 firms in year -3 , for 6 firms in year -2 , and for 5 firms in year -1 , for a total of 57 cases.

${ }^{12}$ Our definition of turnover differs slightly from that in Gilson and Vetsuypens (1993) as we also treat a CEO as having departed even if she retains the position as chairman.

${ }^{13}$ Our classification of reasons for turnover follows prior studies such as Gilson (1989) and Denis and Denis (1995).
} 
the CEO is reported to resign for personal reasons. 56 CEOs (12\%) leave to pursue other interests, while 63 CEOs (13\%) are pressured by the board, shareholders, or creditors to leave. Another 17 (4\%) leave for performance-related reasons.

A large fraction of the CEOs (91 or 19\%) depart because the firm was liquidated or acquired in bankruptcy. Moreover, the stated reason is CEO retirement or normal succession for 70 cases (15\%) and illness or death for 2 cases. The CEO left for a variety of other reasons in 27 cases (6\%), including finishing a transition period, finishing restructuring the company, returning to her own company, investigation, inquiry by a special committee, etc. Finally, we are unable to locate a reason for the turnover in 49 cases $(10 \%)$.

CEO departures are classified as either "forced" or "voluntary". We Follow Huson, Parrino, and Starks (2001) and Yermack (2006) and classify a turnover as forced if one or more of the following is true:

(1) The reported reason for turnover is pressure by the board, shareholders or creditors, or performance related.

(2) The CEO is said to have resigned for personal reasons, to pursue other interests, or no reason is given on departure but the CEO is not employed by another company within a year after turnover.

(3) The firm is liquidated or acquired in bankruptcy and departing CEO is less than 60 years old.

Columns 4-7 of Panel B show the distribution of CEO departures across voluntary and forced turnover. A total of 51\% (241 cases) are classified as forced and 49\% (233 cases) as voluntary. Of the three categories "resigned for personal reasons", "pursue other interests", and "liquidation or acquisition", 45\%, 46\% and 69\%, respectively, of the departures are considered forced. Our data also shows that $55 \%$ of the 49 departed CEOs with "no reason given" for the departure actually fail to enter a new position within our event window, and we classify these as forced turnover as well (as is common in the literature).

It is noteworthy that the "no reason given" category accounts for only $10 \%$ of our sample of turnover observations. In prior studies, the "no reason given" category is typically much larger. 
For example, in Gilson (1989) it is 27\%, and in Denis and Denis (1995) it is 35\%. Our success in reducing the "no reason given" category reflects our search for turnover-related information through Factiva and internet searches not previously done.

The proportion of forced turnover in our sample is much higher than the statistics reported in earlier studies identifying forced turnover. The primary reason is sample selection: we are the first to systematically report forced turnover in bankrupt firms. ${ }^{14}$ Evidence on forced turnover in non-bankrupt firms is found in Parrino (1997), who finds that $13 \%$ of departures are forced, Huson, Parrino, and Starks (2001) who report 16\% forced turnover, and Jenter and Kanaan (2010) where the percentage forced turnover is reported to be $24 \%$.

Interestingly, Lehn and Zhao (2006) who study post-takeover CEO turnover report that $47 \%$ of CEOs are forced out within five years of the acquisition, which is much closer to our $51 \%$. Both corporate acquisition and bankruptcy restructuring lead to dramatic changes in corporate governance. It appears that this governance change also produces a significantly larger proportion of forced CEO turnover than what is normally the case for ongoing firms. While not reported in the table, CEOs that are forced to leave are on average younger (52 vs. 56 years) and have longer tenure (5 vs. 4 years) than CEOs leaving voluntarily.

\subsection{CEO post-turnover employment}

Another major data contribution of this paper is to successfully track CEO post-turnover employment for our 474 departed CEOs. Our tracking procedure begins with identifying whether the CEO stays on as chairman of the board from proxy statements and 10-Ks for the fiscal year after turnover. We then search Factiva, Standard and Poor's (S\&P) Register of Corporations, Directors, and Executives, ${ }^{15}$ and Who's Who in Finance and Industry. ${ }^{16}$

\footnotetext{
${ }^{14}$ Gilson and Vetsuypens (1993) do not identify whether turnover is forced. Gilson (1989) does report some information on forced turnover (in a footnote to his Table 5). However, he categorizes a wide set of turnover reasons as "forced", including what we consider normal succession, such as personal reasons and no reasons given and the CEO is over 60. As expected, his broad definition produces a very high forced turnover percentage: $83 \%$ for distressed firms and $66 \%$ for non-distressed firms.

${ }^{15}$ Standard and Poor writes "The S\&P Register allows users to search a business information database of 90,000 public and private companies which include 400,000 key executives and a database of over 70,000 biographies of top company officials." (Quoted from S\&P's Register of Corporations, Directors, and Executives 2001 edition). We classify a CEO as chairman if references to his title includes the word "chairman" but does not include the words "former chairman", "vice chairman", "chairman emeritus", or "retired chairman."

${ }^{16}$ Marquis Who's Who in Finance and Industry provides access to the professional credentials of senior executives of the largest U.S. firms and other leaders in finance and business. It lists top professionals from the United States and more than 100 other nations and territories. The publication changed name in 2004 to Who's Who in Finance
} 
The S\&P Register and Who's Who are, however, not comprehensive in terms of private company coverage. For CEOs not available in the above sources, we search alternative internet sources and social media, such as Wikipedia, and LinkedIn, and we do direct Google searches. As it turns out, a majority of the post-turnover employment information is obtained from Factiva and internet sources. ${ }^{17}$ After a CEO departs, we follow her employment status for up to three years after turnover. In addition, we record the year, or the actual date when available, for any subsequent employment.

Panel A of Table 3 shows the frequency distribution of the 474 departed CEOs across their type of new employment after departure, classified by forced and voluntary turnover, and the average number of years to new employment. For the overall sample of departed CEOs that subsequently are employed, it takes on average one year before they start in their new job.

- Seven percent (33) of former CEOs stay on as chairman of the board at the old firm, $91 \%$ of which leave the CEO position voluntarily. Ten percent (46) of the CEOs retain an honorary position (such as chairman emeritus, vice-chairman, and consultant) at the old firm, three quarters of which leave voluntarily.

- Twenty-one percent (98) of the top executives become CEO either at another public firm (28 or $6 \%)$ or at a private firm (70 or $15 \%)$. The average time to a new $\mathrm{CEO}$ employment is 1.3 and 1.4 years, respectively, and $54 \%$ and $63 \%$, respectively, of these CEOs are forced to leave the sample firm. A similar number of departing CEOs become a non-CEO top-executive or director at another public firm (52 or $11 \%$ ) or at a private firm (44 or 9\%).

- Of the remaining cases, 4\% (19) of former CEOs become a consultant or politician, 5\% (26) are subsequently self-employed, and 33\% (156) have no new employment. The latter category includes retirement, death, sent to jail, book writer, pursue a degree, or that the former CEO cannot be found in any of the sources mentioned above for at least three years after turnover.

We also collect information on the industry and the SIC code, book assets, sales, and number of employees for the companies where the departed CEOs subsequently work. For public companies, and Business.

${ }^{17}$ Our access to Factiva and social media allows a much better coverage than earlier important studies in this area, such as Gilson (1989). 
we rely on Compustat to obtain this information. For private companies, we search a multitude of sources, including Capital IQ, Factiva, Business Week, Forbes, Wikipedia, LinkedIn, and we again do direct Google searches. Panel B of Table 3 shows characteristics of the new firms that hire the departed CEOs. Only one-third of the new firms (29\%) are in the same 2-digit SIC industry as the old firm. For departed CEOs subsequently employed as CEO or another top-executive at a public firm, the new company is of similar size as the old firm. In contrast, private firms hiring departed CEOs are significantly smaller than the old firms that the CEOs worked for, with median sales of $\$ 118-\$ 270$ million vs. $\$ 851-\$ 862$ million for the old firms.

Table 4 reports the percent distribution across the type of new employment by departure year relative to bankruptcy filing (Panel A), CEO age (Panel B), and reason for CEO departure (Panel C). There are a few discernible differences in the type of new employment across the year of CEO departure. One is that there is a slightly higher fraction of CEOs departing prior to bankruptcy filing (year -2 through 0) that stay with the firm as chairman (10\%-17\%) or retain an honorary position (also 10\%-17\%) compared to CEOs departing in subsequent years.

Of CEOs departing in years 0 an thereafter, a large proportion (35\%-46\%) do not find any new employment. At the same time, of those who find a new job, many become a top executive at another firm, which is somewhat surprising. One explanation could be that some of the turnover observed during this time period is related to a turnaround specialist finishing the restructuring job and moving on to another company. Of the departing CEOs during this period, 45 are in fact restructuring specialists, and more than half of these become $\mathrm{CEO}$ or non-CEO executive in another company. In addition, the CEOs that depart during bankruptcy restructuring and obtain full-time employment as an executive are mainly those that are newly hired around Chapter 11 filing. The incumbent CEOs are less likely to obtain full-time employment after departure and therefore, are expected to experience large personal losses. CEOs are forced out mainly by creditors during restructuring. The CEOs that are forced out are likely to be those that have high risk preference and may engage in potential risk-shifting, which may not be treated as a negative sign on quality by shareholders at a difference company. We will come back to this point in later sections.

As shown in Panel B of Table 4, CEOs older than 60 years when they depart have a relatively high likelihood (45\%) of not being employed again, probably because many of these CEOs chose to retire. On the other hand, CEOs below age 50 are more likely to subsequently become a top 
executive at another firm (29\%). Finally, Panel C shows that CEOs resigning to pursue other interests are relatively likely to move on and become CEO of another firm (29\%), while CEOs leaving as part of retirement or normal succession are relatively likely to stay on as chairman (10\%). CEOs resigning for personal reasons or are pressure by the board, shareholders or creditors have a relatively high change of retaining an honorary position with the firm (11\%-15\%). In contrast, CEOs of firms that are liquidated or acquired quite often up without any new employment (41\%), as do CEOs pressured to leave (also 41\%).

\subsection{Statistics on newly hired CEOs}

To determine whether a newly hired CEO, replacing the departed CEO, is internally promoted or externally hired, we search proxy statements, 10-Ks, and Factiva. If the CEO is hired from the outside, we identify from $10-$ Ks and news articles whether she is a turnaround specialist. ${ }^{18}$ Through this search, we are able to identify 394 newly hired CEO, 71 of which are restructuring specialists.

We also collect information on the most recent employment of the externally hired CEOs, including company name, job title, length of employment, and the firm's SIC code, sales and assets. When the previous employer is a private firm, we search Capital IQ, Forbes, and Business Week to retrieve information on industry and firm size. In addition, we identify whether an employment contract including severance agreement is offered to the newly hired external CEOs and quantify the expected severance payments based on the salary and bonus they are offered.

Panel A of Table 5 shows selected characteristics of the 394 newly hired CEOs by year. Across the whole sample period, a majority of new CEOs (57\%) are hired from the outside: $18 \%$ are turnaround specialists (i.e. with prior experience in turning around troubled companies), and $41 \%$ has prior CEO experience (these two categories sum to $59 \%$ because they overlap slightly—when a specialist may also be a CEO at another company). The average age of the replacement CEOs is 52 years, which is slightly younger than the departing CEOs (mean age of 54 years). The highest fraction of new CEOs hired from the outside are in the post-bankruptcy period (years 1 and thereafter), while the highest fraction of specialists are hired while the firm is in bankruptcy (years 0 and 1 ).

\footnotetext{
${ }^{18}$ We do not record cases where a restructuring specialist is hired in a non-CEO top executive position with the firm, such as chief financial officer (CFO) or chief operating officer (COO).
} 
Panel B reports characteristics of the 225 replacement CEOs hired externally, divided by whether she was a CEO or partner, or a non-CEO executive with her previous firm. The newly hired CEOs has a tenure of on average 5.7 years with their previous employers, $41 \%$ of which are publicly traded and $29 \%$ of which are in the same 2-digit SIC code industry as the sample firm. New CEOs with no prior CEO experience used to work for a firm of significantly larger size than new hires with prior CEO experience (average sales of $\$ 27.6$ million vs. $\$ 8.2$ million). There are no significant differences across their backgrounds with respect to whether the new CEO gets an employment contract, or the size of severance pay—neither in dollar terms, nor in percent of salary and bonus. ${ }^{19}$

\subsection{Cross-sectional analysis}

\subsubsection{Determinants of CEO turnover}

We next examine the determinants of CEO turnover for financially distressed firms. Table 6 presents coefficient estimates from multinomial logit regressions of voluntary versus forced turnover. The sample is 1,625 firm-years with a full set of control variables. ${ }^{20}$ The benchmark category is 1,294 firm-years without any CEO turnover. We include industry fixed effects (based on 2-digit SIC codes) to control for the impact of exogenous shocks to specific industries. The table contains four regression specifications, separately entering variables capturing the control rights of shareholders, secured creditors and unsecured creditors. The number of voluntary and forced turnover in each regression model is shown at the bottom of the table.

The first two independent variables included in all the regressions are indicators of the time period relative to bankruptcy restructuring. The variable Before takes the value of one if the firmyear observation is years -3 and -2 relative to Chapter 11 filing, and zero otherwise. The variable During indicates that the firm year observation is from years -1 to 1 . Since a restructuring effort typically is initiated prior to the actual bankruptcy filing, this period represents the midst of the distressed restructuring. The positive coefficients for During indicate that the CEO turnover rate, both voluntary and involuntary, is significantly higher around Chapter 11 filing compared to either

\footnotetext{
${ }^{19}$ Dollar amount of severance pay is based on CEO's salary and bonus in the year of hiring.

${ }^{20}$ The exception is the indicator for Large institution, where 49 cases are missing because they do not have valid cusips.
} 
before filing or after emergence. Moreover, the coefficient for During is significantly higher (at the $5 \%$ level) for forced turnover than for voluntary turnover. Thus, the likelihood of forced turnover is higher around the year of bankruptcy filing also in the cross-section, consistent with the summary statistics presented above in Table 2 .

The next set of variables describes characteristics of the CEO. The first variable, Age, captures the CEO's age at departure. Older CEOs are more likely to leave voluntarily, perhaps due to retirement, but are not more likely to be forced out. Also, the coefficient for Ownpct is negative and statistically significant at the $1 \%$ level in explaining the voluntary turnover decision. CEOs with large equity ownership have their wealth closely tied to the company's value, thus having strong incentives to stay on while trying to rescue the firm. Neither CEO tenure, nor a dummy variable indicating that the $\mathrm{CEO}$ is chairman of the board produces significant coefficients.

Most of the firm characteristics have no or a marginally significant impact on the turnover probability. There is some evidence that the degree of financial distress, measured by operating income and leverage, helps predict the probability that the CEO is forced to leave. The lower ROA and the higher Leverage, the higher is the likelihood of forced turnover (significant at 10\% level), consistent with earlier studies (see e.g. Huson, Parrino, and Starks (2001)). The coefficients for Size and Tangibility, however, are insignificant across all specifications.

To control for shareholder and creditor control rights, the regressions include indicators for four different types of stakeholders: large institutional investors, bank lenders, unsecured bond holders, and holders of other liabilities (primarily suppliers and customers). In the regression analysis, we interact these variables for shareholders/creditor control rights with time dummy variables. The interaction terms intend to capture the effects of shareholders and creditors on CEO turnover in the different time periods around Chapter 11 filing.

The first variable, Large institution, takes the value of one if the total institutional ownership exceeds $25 \%$ (from 13-F filings). This threshold is close to the mean level of institutional ownership for our sample firms in the fiscal year before Chapter 11 filing.

The second variable, Large bank loan, takes the value of one if the ratio of bank loans to total liabilities is higher than $50 \%$. The intent of this variable is to capture the potential influence of large bank lenders on corporate governance. In addition, we consider the actual bank monitoring and governance through DIP financing. Prepetition lenders play a significant role in providing 
DIP financing in recent years (Dahiya, John, Puri, and Ramirez (2003)). Their reasons for making such loans range from enforcing governance and the priority of their prepetition loans - the rollup provision (Skeel (2003)) - to continuing prior lending relationship (Li and Srinivasan (2011)). ${ }^{21}$ More than three quarters of the DIP financing is provided by prepetition lenders in our sample. The variable $D I P$ indicates that the DIP loan is provided by the prepetition lenders, enforcing close governance of the firm through these loans.

Third, we consider whether public unsecured debt and other non-tradable liabilities account for a large portion of the capital structure. We define two dummy variables, Large bond liability and Large nondebt liability. They indicate that public bonds and non-tradable liabilities, respectively, account for more than $70 \%$ of the total liabilities. With large outstanding unsecured debt CEOs are less likely to forced out by creditors before bankruptcy as these creditors are much less concentrated. In addition, unsecured debt is associated with less restrictive covenants compared to bank loans.

As shown in Table 6 , the interaction term During $\times$ Large institution produces a negative coefficient, significant at the $5 \%$ level, in the regressions for forced turnover. This suggests that CEOs in firms with high institutional ownership are less likely to be forced out during the restructuring period compared to firms with low institutional ownership. Although this result at first may seem counter intuitive, it is possible that the institutional investors that ultimately remain have selected to retain their stake when these portfolio firms become distressed.

Coelho, Taffler, and John (2010) show a significant decline in institutional ownership from eight quarters before to four quarters after Chapter 11 filing. Through 13-D filings, Jiang, Li, and Wang (2011) find that only $7 \%$ of the firms in their sample have active participation by hedge funds before entering Chapter 11 and for only $4 \%$ of the firms do hedge funds file a 13-D during the restructuring process. It is plausible that the institutional investors who keep large ownership stakes have more confidence, while the ones that reduce institutional ownership have less confidence in incumbent managers. Institutional investors may reduce their equity holdings while at the same time forcing out the manager. This explains why we observe more forced turnover when the institutional ownership is low. On the other hand, the conflicts of interests between shareholders and creditors become severe when a firm is in distress. CEOs chosen by the shareholders have a goal

\footnotetext{
${ }^{21}$ DIP lenders often request to package their existing loans to the debtor into the DIP loan to increase the seniority of prepetition loan, commonly know as the rollup provision.
} 
of increasing share value, possibly through asset substitution and asset stripping. These CEOs may be regarded by shareholders as being of high quality. Around Chapter 11 filing, when control shifts from shareholders to senior creditors, such CEOs may be forced out by powerful senior creditors.

Model (2) includes interaction terms between Before and During, and Large bank loan, as well as an indicator that senior creditors provide DIP financing. The interaction variables captures potential variances over the restructuring in the importance of large banks as monitors. However, none of the interaction variables are significant. In contract, the variable $D I P$ enters the regression for forced turnover with a highly significant and positive coefficient. That is, DIP financing largely captures the role of large lender governance for the selection of CEO. ${ }^{22}$

Next, we consider the role of unsecured creditors in CEO turnover. We find that firms with large nondebt liabilities are less likely to force out their CEOs during restructuring. Nondebt liabilities mostly come from supplier and customer financing, which is less concentrated compared to bank loans. The suppliers and customers do not play active governance roles such as seeking board representation. Thus they have less power in forcing out a CEO with poor performance. Also the CEO firing decision may be even irrelevant to suppliers and customer as long as the shortterm financing from these stakeholders is paid on time. Hertzel, Li, Officer, , and Rodgers (2008) show that bankruptcy filing has large negative valuation impact on suppliers. During bankruptcy restructuring suppliers have strong incentive to keep their business relationship with the CEO in place, hoping for company survival and continuing this relationship after company emerges. Our results are consistent with example of Hancock Fabrics case presented in the introduction.

All regressions control for prepackaged filings, which produce a statistically insignificant coefficient. In unreported tests we adopt logit regression on CEO turnover versus no turnover and find the coefficients to be largely consistent with the forced turnover. The only difference is that the effect of large institutional investors becomes somewhat stronger in the years prior to Chapter 11 filing.

\footnotetext{
${ }^{22}$ When we drop DIP from the regressions, the interaction variable During $\times$ Large bank loan generates a positive and marginally significant coefficient (at the $10 \%$ level).
} 


\subsubsection{Determinants of the new hiring decision}

We study the new hiring decision next. Table 7 shows the multinomial logit regression results on whether the newly hired CEOs are internal replacements or external succession. We use the same set of control variables as above. First, we observe that the sample firms are more likely to hire an internal replacement prior to bankruptcy, and equally likely to hire internal or external replacements during restructuring compared to keeping the current $\mathrm{CEO}$. The coefficient estimates on other variables are largely consistent with empirical results from voluntary and forced turnover. This seems intuitive as forced turnover is often associated with outside hiring.

To model the decision of firing and hiring jointly we adopt two additional models (not tabulated in the paper). The first model is a multivariate regression with five outcomes: voluntary turnover with internal succession, voluntary turnover with external succession, forced turnover with internal succession, forced turnover with external succession, and no turnover. This regression specification is similar to that in Parrino (1997). We find results that are similar to but provide more inference to Parrino (1997). Consistent with his finding, older CEOs are more likely to voluntary leave with either internal or external succession. Firms with better operating performance are less likely to force out their CEOs with external replacements. Firms with high leverage are more likely to force out current CEOs with external succession. In addition, we find that firms with large institutional investors in place are less likely to choose external succession. Their preferred choice is internal replacement if the incumbent CEO leaves. Firms with strong monitoring of lenders are more likely to force out CEOs with either internal or external succession. Consistent with earlier findings, firms with large nondebt liabilities are less likely to force out the CEO during restructuring.

The second model is in the spirit of Borokhvich, Parrino, and Trapani (1996), where we adopt a bivariate probit model on turnover and external succession. The advantage of the bivariate probit mode is that it models turnover and the decision on the new hiring jointly. As expected, the correlation coefficient between turnover and external hiring models is significant at the $1 \%$ level, suggested by the likelihood ratio test. We find that CEOs are more likely to experience turnover and new CEOs are more likely to be hired externally in both before and during restructuring compared to post-emergence. Older CEOs are more likely to be replaced by external hiring. CEO stock ownership negatively affects both turnover and whether the replacement is an outsider. We 
also find firms with large institutional investors are less likely to turn over CEOs and internal replacements are more likely upon turnover. The results are similar for nondebt liabilities holders. Firms with close bank monitoring and governance are more likely to fire CEOs and replace them with external candidates.

\section{Estimating CEO bankruptcy costs}

Our measure of CEO personal bankruptcy costs use information on severance pay ("golden handshakes") and changes in all relevant CEO compensation items between the old and new (if any) employment. In this section, we start by presenting data on severance pay. We then summarize the present value of the change in total CEO compensation, including severance pay, which provides an estimate of the magnitude of CEO bankruptcy costs. Finally, we analyze whether this present value is impacted by creditor activism throughout the bankruptcy process.

\subsection{CEO severance pay statistics}

CEO employment contacts frequently specifies a minimum separation pay if the CEO is dismissed for "good reasons" and not "for cause". The term "for cause" typically refers to willful misconduct or breach of fiduciary duties, but it does not, normally, include incompetence or poor performance (Schwab and Thomas, 2004). A CEO leaving voluntarily without good cause before expiration of the contract period typically is not entitled to separation pay. However, boards may - and frequently do-award severance pay discretionarily. Also, CEOs sometimes negotiate to retain employee status, for example by serving as board chairman, which implies a form of severance payment. Separation agreements are negotiated and signed right before the CEO leaves the company. These contracts also typically include non-compete and non-solicitation provisions for periods of one or two years. ${ }^{23}$

While ours is the first study documenting severance pay around Chapter 11 filings, Fee and Hadlock (2004), Yermack (2006) and Goldman and Huang (2011) provide evidence on severance

\footnotetext{
${ }^{23}$ Goldman and Huang (2011) describe the following example (p. 4), which was reported on www.redherring.com February 20, 2007: "Former Dell CEO Kevin Rollins will receive a $\$ 5$ million severance package, according to documents filed by the computer maker, after Mr. Rollins was forced out by founder and Chairman Michael Dell. The filing also revealed that Mr. Rollins has agreed not to sue or compete with the company. In the Separation Agreements, Mr. Rollins provided a general release of claims against the company and agreed to certain non competition and non solicitation obligations for a period of 12 months following his termination...".
} 
pay outside of financial distress. These papers show that dismissed CEOs are far more likely to receive severance pay than CEOs who leave voluntarily. Goldman and Huang (2011) also find that boards exercise substantial discretion over severance pay in order to facilitate a smooth transition from the old to the new CEO.

We collect severance pay awarded to departing CEOs from 10-Ks and proxy statements through Edgar and Factiva news search. Following Yermack (2006), we identify whether the severance pay is based on an explicit employment contract or is discretionary. The discretionary separation pay includes lump-sum cash payments, consulating agreements, loan forgiveness, adjustments to pension, and equity compensation adjustments including continuation of vesting of options and restricted stocks. For a few cases where Factiva specifies only the total amount of severance, we assume that the separation pay is contract based in its entirety.

Table 8 documents the severance paid to the CEO by year of departure (Panel A), reason for turnover (Panel B), and type of new employment (Panel C). Of the total sample of 474 departed CEOs, $28 \%$ receive a severance payment. The average (median) severance pay conditional on receiving severance is $\$ 3.5$ million ( $\$ 1.6$ million), of which $\$ 1.7$ million ( $\$ 0.5$ million) is according to existing contracts and another $\$ 1.8$ million ( $\$ 0.4$ million) is discretional (negotiated upon departure). This represents on average an amount close to six times the CEO's annual pre-filing salary.

As shown in Panel A, CEOs leaving relatively early in the process are most likely to receive severance pay. Thus, $39 \%$ of CEOs leaving in year -1 and $32 \%$ of those leaving in year 0 (the year of filing) receive severance. The average amount of severance paid is, however, highest in years 0 through 2 , with a relatively large fraction of the severance being discretional in year 0 and contractual in years 1 and 2 .

Panel B of Table 8 shows that CEOs pressured by the board, shareholders, or creditors receive the highest average severance payment ( $\$ 7.7$ million), while CEOs leaving to pursue other interests or with no reason given receive an average separation pay of $\$ 1.8$ million and $\$ 1.3$ million, respectively. As shown in extant work, CEOs that are forced to leave more often receive a severance package (32\% vs. $24 \%$ ) and tend to receive a higher severance pay (mean $\$ 4.1$ million vs. $\$ 2.7$ million) than CEOs who leave voluntarily .

Panel $\mathrm{C}$ shows that CEOs staying on as chairman with the old firm do not receive severance 
payment. In contrast, CEOs retaining an honorary position with the firm receives severance in $46 \%$ of the cases, and the average payment is $\$ 2.3$ million. The highest average severance of $\$ 10.5$ million is paid to the one-quarter of the departing CEOs that subsequently end up being self-employed, and most of which is discretional.

\subsection{CEO income and wealth-change statistics}

We collect annual data on CEO stock holdings and compensation starting three fiscal years prior to bankruptcy filing and ending three fiscal years after the case is resolved. For firms that are liquidated in bankruptcy, the compensation data ends in the fiscal year in which the case resolution is confirmed.

The compensation items we collect include salary, bonus, long-term incentive plans (LTIP), value of restricted stock awards, number of options granted, exercise price, grant date, maturity date, and value of grant. ${ }^{24}$ We define cash pay as the sum of salary, bonus, and LTIP paid in that year. ${ }^{25}$ We define grants as the total value of all restricted stock and options granted during the year. Option value is calculated using the Black-Scholes model. ${ }^{26}$ Total pay is the sum of cash pay and grants during the year. We use the value of equity (including both shares held and unexercised options) to measure CEO equity wealth. Our compensation measures are all based on constant 2009 dollars.

The estimation of CEO post-turnover employment income requires us to make a few additional assumptions, the details of which are described in Table 9. In brief, we use the following procedure:

(1) If the departed CEO becomes CEO at another public company, we first check if the compen-

\footnotetext{
${ }^{24}$ Due to the adoption of FAS123, companies report option and stock awards in a slightly different form after 2005. For years 2006-2009, we rely on ExecuComp tables "Plan Based Awards" and "Outstanding Equity Awards" to calculate the value of options awarded. To estimate the value of stock awards, we multiply the number of shares granted with the year-end closing price of the common stock.

${ }^{25}$ We do not include "all other cash compensation" listed in their pay table because this component often includes severance pay or other types of discretionary payments on an individual basis. Also, all other cash compensation is not a major pay component.

${ }^{26}$ We follow Core and Guay (2002) to estimate the grant date value of options. Since executives frequently exercise their options early, this approach assumes that the expected time to exercise is $70 \%$ of the option's stated maturity. When the grant date is missing, it is assumed to be July 1st of that year. The expected stock return volatility is measured as the annualized standard deviation of daily stock returns over the fiscal year in which the grant was made. A firm must have 50 observations for its volatility to be estimated. If there are not enough observations for volatility estimation, we use the median of the volatility distribution of all firms in ExecuComp in a given year as a proxy. Following the practice of ExecuComp, we replace the volatility with its 5th and 95th percentile, respectively, if it is either below the 5th percentile or above the 95th percentile of all observations in a given year. Expected dividend yield is the ratio of cash dividends paid in the fiscal year of the grant and the fiscal year-end stock price. The treasury bond yield corresponding to the option's expected time to maturity is used as the risk-free rate.
} 
sation is reported in ExecuComp for that firm. ${ }^{27}$ If the firm is not found in ExecuComp, we find another firm on ExecuComp that matches the 2-digit SIC industry and size of the firm, and use it's CEO pay as a proxy. If the CEO becomes CEO at a private company, we again use the CEO pay for the public firm that has the same 2-digit SIC code and is the closest in sales, and adjust it with an $18 \%$ cut in salary and bonus and a $30 \%$ cut in grants following Gao, Lemmon, and Li (2011).

(2) If the departed CEO becomes a non-CEO executive (e.g. COO) or director at another public firm, we use the average non-CEO pay at the closest SIC-size match in ExecuComp. If the firm is private, we adjust the matched firm's pay, as described above.

(3) For departing CEOs who become consultants and politicians, we assume an average income of $\$ 300$ thousand (in 1995 US dollars). ${ }^{28}$

(4) For CEOs who become self employed, we use the one-digit SIC and the median pay of a company at the bottom decile in number of employees as a match.

(5) For CEOs who obtain an honorary position or end up in the category no new employment, we assume an income of zero.

Table 10 reports the average and median CEO income at the old firm and in the new position (post-turnover) as well as income changes in both dollars and percentage. We notice extreme large values on the percentage of total compensation change, mainly caused by a negligible number of firms where CEO's income prior to departure is close to zero. A CEO may take a deep temporary cut on her income in the year before departure. However, we feel a zero income, indicating a massive percentage increase in pay after departure if she obtains new employment, does not reflect the equilibrium wage a CEO should receive. Therefore, we drop observations that lie in the top five

\footnotetext{
${ }^{27}$ ExecuComp covers S\&P large cap 500, midcap 600 and small cap 400 firms.

${ }^{28}$ The assumption of $\$ 300$ thousand in annual consulting income for departed CEOs is based on the consulting agreement for CEOs actually observed in our sample. For example, Donald Amaral of Coram Healthcare was paid $\$ 200$ thousand per year in his role as a consultant to the company. The consulting fee for Robert Kaufman to Carematrix Corp. was $\$ 250,000$ per year. Flag Telecom agreed to pay Andres Bande $\$ 350,000$ per year as consultant. In some cases, the total consulting fee is listed (rather than an annual fee). For example, Lodgian, Inc. agreed to pay Robert Cole a total fee of $\$ 750,000$ for his consulting services, while Covanta Energy agreed to pay Scott Mackin a total of $\$ 1.75$ million. The 1995 dollars is used because the first CEO becoming consultant in our sample occurs in 1995.
} 
percentile in the distribution of percentage change of total pay and CEOs whose total pay before departure is zero in Table 10.

Panel A shows the total cash compensation including salary, bonus, and long-term incentive plans. Panel B adds the equity grants (stock awards and option grants). In addition to the 442 departed CEOs, the table also shows information for 121 CEOs that remain CEO at the sample firm three years after emergence from bankruptcy. For the CEOs that retain their position we measure their income change from the first year of their hiring or the start of our sample to the last fiscal year with available compensation data. Figure 2 shows the histogram of the change in total compensation for 121 CEOs retaining their position at the old firm and 80 departing CEOs that obtain a CEO position at a new public or private firm. Both distributions are negatively skewed with the mean much lower than the median. We report both mean and median values in all tables on compensation changes with a flight focus on the median.

Interestingly, departing CEOs that stay on as chairman or subsequently are employed by a public firm as either CEO or non-CEO executive do not experience any significant drop in salary and bonus. These CEOs even experience somewhat increase in their total pay. CEOs that retain their position with the sample firms see a slight increase in their salary and bonus (median 26\%). This may reflect the preference of these CEOs receiving cash compensation rather than grants. In contrast, those that only retain an honorary position at the old firm, move to a private firm, become a consultant or politician, or self-employed, all experience a substantial income drop. Across all 563 CEOs (including the 121 executives that stay at the helm of the bankrupt firm), the median (average) salary and bonus declines by $-60 \%(-18 \%)$; and the median (average) total pay drops by $-76 \%(-19 \%)$. The average income drop is particularly large for CEOs that do not find any subsequent employment, with an median decline in total income of $-\$ 1.1$ million (average $-\$ 3.7$ million), a $100 \%$ drop.

The last two columns of Table 10 report our CEO bankruptcy cost measure, calculated as the present value $(\mathrm{PV})$ of the income change assuming that the $\mathrm{CEO}$ will continue to earn the new income level until age 65 and thereafter zero, with a $10 \%$ discount rate, plus any separation pay received by the departing CEO. The PV of the average decline in total pay is a stunning $-\$ 13.8$ million across all CEOs, and highest for departed CEOs that subsequently become self-employed with a PV of $-\$ 29.6$ million. Using median we find CEOs that do not obtain new employment and 
those that become consultant experience the largest costs.

Table 11 shows the income change and the associated PV of loss across different subsamples. As shown in Panel A, CEOs with forced departure experience the largest income loss with a median PV of the decline in total pay of $-\$ 4.3$ million (average $-\$ 22.9$ million). The corresponding PV of income drop for CEOs leaving voluntarily or who retain their CEO position with the sample firm is $-\$ 1.3$ million (average $-\$ 6.9$ million) and zero (average $-\$ 8.3$ million), respectively.

Panel B reports the income change by major type of subsequent employment for the departed CEOs. As expected, departed CEOs without any new employment stand the most to loose, with a $\mathrm{PV}$ of the median drop in total pay of $-\$ 4.4$ million. In contrast, CEOs who subsequently are employed by another firm (private or public) experience a much smaller PV of the decline in total pay of a mere $-\$ 0.4$ million.

Panel $\mathrm{C}$ shows how the income varies with the year of departure relative to bankruptcy. CEOs leaving immediately before or during bankruptcy (years 0 to 1) experience a drop in total pay with a median PV of $-\$ 3.0$ million (average $-\$ 20.0$ million), while the corresponding number for CEOs departing in year 2 and thereafter (year -2 to -1 ) is only $-\$ 1.9$ million (average $-\$ 2.1$ million).

From Panel D, it is obvious that CEOs of age more than 60 see the largest declines in annual total pay (median $-\$ 0.8$ million) but experience the smallest bankruptcy cost (median zero). On the other hand, CEOs that are less than 50 years old see a much higher PV of the compensation loss (median $-\$ 4.4$ million) due to their relatively young age. Panel E shows that the income loss is the largest for CEOs with a tenure exceeding six years, possibly because these CEOs also had the highest pay to start with. They may have a large component of their pay tied to power and entrenchment.

Finally, Panel F shows the income change by whether the departing CEOs are the incumbent that are in place at the beginning of our study sample period or new CEOs that are hired during our sample period, and whether they depart before Chapter 11 filing, during restructuring, or after emergence. The group of CEOs that experience largest decline (in both the median and the mean) is incumbent CEOs that leave after Chapter 11 filing. These CEOs are tainted by the bankruptcy filing significantly. Interestingly, CEOs that are hired before Chapter 11 filing and depart during restructuring also experience large personal loss. However, if the incumbent CEOs are able to help the company go through reorganization they experience much less income decline. 
Table 12 provides further evidence on the income change and the personal loss of incumbent CEOs versus newly hired CEOs, and forced versus voluntary departure. Panel A shows that incumbent CEOs who find new full-time employment experience a slight reduction (increase) in their median (average) compensation. The median PV of income change for this group as a whole is only \$-0.2 million, suggesting they suffering relatively modest personal bankruptcy costs. In contrast, the incumbent CEOs who do not receive new employment or obtain other type of employment suffer large personal losses. Panel B provides interesting evidence that CEOs who voluntarily leave suffer lower personal losses compared to those forced out mainly by senior creditors. CEOs that leave voluntarily and become CEOs of another public company experience a large increase in their income (median 67\%). Taken together our evidence suggests that creditors play an active role in forcing out low quality CEOs.

Overall, our results suggest that CEOs suffer substantial losses in total compensation when their firm files for bankruptcy, and in particular if they also loose their job.

\subsection{Cross-sectional analysis}

\subsubsection{Determinants of CEO compensation}

Table 13 presents regression an analysis of the determinants of CEO compensation. The dependent variable in the first three regressions is the logarithm of total pay while the dependent variable for the last three regressions is the proportion cash compensation (salary and bonus) of total pay. We use OLS regressions for total pay and Tobit regressions for the proportion cash compensation, since the latter is bounded between zero and one. The regressions control for the time period relative to Chapter 11 filing, whether the CEO is newly hired, internally or externally, CEO personal information such as age, tenure, chairmanship, and stock ownership, and firm characteristics including size, profitability, leverage, and asset tangibility.

The first model shows that the firms pay their CEOs less on average, both before and during restructuring compared to after reorganization. When adding CEO and firm characteristics in models (2) and (3), the negative coefficient for Before becomes insignificant. The coefficient for During is still significant, however, suggesting that CEOs are paid less during restructuring, confirming the comparison of our sample CEOs to their matching peers presented earlier. 
Importantly, the coefficient for Internal is negative and the one for External is positive, indicating that internal replacements are paid less and external replacements are paid more than incumbent CEOs. This is consistent with Gilson and Vetsuypens (1993) who show that newly appointed CEOs with ties to departing CEO are typically paid $35 \%$ less and outside replacements are paid 36\% more than the CEOs they replace. Translating the logarithms, our coefficient estimates suggest that internally promoted CEOs are paid $52 \%$ less and external replacements are paid $65 \%$ more than staying CEOs. ${ }^{29}$ Our estimates are higher than those reported by ?. The caveat is that their numbers are based on a nonparametric comparison while we control for key CEO and firm characteristics. The last three columns show that new internal CEOs, and to some extent externally hired CEOs, have a larger proportion of their pay in stock and option grants. Since newly hired CEOs usually do not have wealth tied closely with company performance, awarding grants is one way to achieve a desired performance-sensitivity.

The relation of CEO and firm characteristics to compensation is largely consistent with prior literature. For example, older CEOs have lower total compensation and most of their pay is in the form of cash. This is intuitive as CEOs who are close to retirement age have less bargaining power and less risk appetite, considering cash more valuable relative to grants. Also, CEOs with higher stock ownership prefer cash compensation as a way to diversify and hedge their wealth. In addition, we find firm size to affect both the level and structure of pay. CEOs receive higher pay and a lower fraction cash compensation the larger the firm. Finally, CEOs receive more cash pay in firms with high leverage, probably because equity is valued less for firms approaching financial distress.

\subsubsection{Effects of expected bankruptcy costs on turnover and compensation}

Table 14 shows coefficient estimates for the probability that a departed CEO finds new employment and her wealth change, using a subset of 442 CEO turnover cases with information on all control variables. We use a logit model for the probability that the CEO is rehired by another company (Model (1)). The dependent variable takes the value of one if a departing CEO stays as the chairman of the board or is hired by another public or private company as a CEO or non-CEO executive,

\footnotetext{
${ }^{29}$ The regression coefficient show that internal CEOs are paid 0.726 less than incumbent CEOs in logarithm of total pay while external hires are pay 0.499 more in logarithm of total paid. This translates into $\left(1-e^{-0.726}\right) * 100=52 \%$ less pay for internal successions and $\left(e^{0.499}-1\right) * 100=65 \%$ more pay for external replacements.
} 
and zero otherwise. Model (2) presents the results from an OLS regression for the present value of income change discounted at a $10 \%$ rate plus total severance payments, if any, in millions of dollars. These regression models intend to identify the determinant of CEO personal bankruptcy costs. The independent variables include time period dummies, CEO age, tenure, chairmanship, and whether the company is liquidated.

The variable During produces a negative and significant coefficient. This suggests that CEOs who leave during the restructuring are less likely to be employed by another company and therefore, are more likely to become self-employed or fail to find new employment. Neither of the time variables are significant in the wealth regression.

Turning to the CEOs characteristics, managers that are older are less likely to find new employment as are managers whose firms are liquidated in bankruptcy. Older CEOs are likely to retire after departure. Older managers have, however, overall lower personal costs of bankruptcy. Since the opportunity cost of a departing CEO of not finding a job after age 65 is virtually zero by our definition, older CEOs lose less upon departure. Liquidation may result from either low going concern values or unsuccessful bargaining of parties in Chapter 11. Both scenarios suggest the low quality of the departing CEO.

Also, there is some evidence that CEOs with longer tenure may be entrenched, having trouble to find new employment and loosing more rents when leaving the firm. Alternatively, CEOs that work in the firm for a long period of time may possess a larger portion of firm specific skills. These skills may be hard to transfer to other firms or industries, and are therefore valued less in the labor market. Both explanations suggest CEOs with longer tenure incur larger personal costs upon departure. Finally, the coefficient for Chairman is negative and marginally significant in the wealth regression. CEOs that are chairman have more to lose after departure, largely reflecting the loss of the rents component of their compensation.

In Tables 15 and 16 we study how the expected personal bankruptcy costs affect the turnover probability of and compensation contract of the CEO. First, we use the predicted values from the regression in Table 14 for the probability of being rehired and the present value of income change for our departing CEOs. These predicted values provide an ex ante estimate of the expected rehiring probability and expected bankruptcy costs for all CEOs. Next, we include this ex ante measure in multinomial logit regressions on voluntary and forced turnover as shown in Table 15. Since certain 
CEO characteristics are already used to predict the probability of being rehired and the present of income change, we do not include these variables in the turnover and compensation regressions.

Table 15 shows that the expected probability of being rehired reduces the probability of a CEO voluntary leaving, while failing to explain the likelihood of forced turnover. This indicates that CEOs often stay with the current firm also when they have good outside employment options. It is possible that these CEOs are of better quality compared to other CEOs in our sample. They may have more wealth at stake and have more confidence to turn around the company and thus decide to stay. Also, it is possible that the CEOs who do not mind being self-employed or retire are more likely to leave. On the other hand, if they expect to experience large income drop by departure they are less likely to voluntary leave. The large income drop could result from their loss of rents enjoyed by their current position. Therefore, they would be willing to stay with company till they get forced out. Our results provide a rationale explanation on voluntary turnover decision, which has not been documented in the prior literature.

Table 16 shows the relation of total amount and structure of compensation and CEO expected bankruptcy costs. Our results indicate CEOs that are more likely to be employed by another company receive larger total compensation. This possibly reflects the quality and the negotiation power possessed by these CEOs. These CEOs are more likely to receive grants in their compensation. Our results also indicate those CEOs that are either more entrenched or have tendency to retire receive compensation in the form of cash. The coefficient estimate of expected PV of total compensation change suggest that CEOs who expect to lose more after departure are likely to extract rents prior to departure and pay themselves a higher compenation. In an interesting case, Enron's CEO and Chairman Kenneth Lay received $\$ 1.3$ million of salary, $\$ 8.2$ million in bonus and long-term incentive plans, in addition to about $\$ 8$ million in stock and option grants in the fiscal year end right before Chapter 11 filing. Our results also indicate that CEOs that are expect to gain after departure are more likely to pay themselves cash. Taken together with results in Table 15, CEOs that are likely to gain from departure are more likely to voluntarily leave, and receive more cash compensation before leaving. Other key explanatory variables retain their statistical significance with the inclusion of the ex ante probability of being rehired and PV of income change.

Overall, our results indicate the ex ante probability of rehiring and expected income loss strongly predict the decision of CEO voluntary turnover and their incentive contract. 


\section{Conclusion}

Personal CEO bankruptcy costs may affect the financing and investment policy of firms. Earlier estimates of the magnitude of such costs have suffered from lack of data on CEO career changes following bankruptcy. Absent such data, bankruptcy costs are estimated assuming a complete loss of income, causing bankruptcy cost estimates to be overstated. We provide large-sample estimates of CEO personal bankruptcy costs that, for the first time, account for the CEO's post-bankruptcy employment income.

We track CEO employment changes using 342 U.S. public companies filing for Chapter 11 between 1995 and 2008. Surprisingly, one-half of the incumbent CEOs maintain full-time employment. Of these, two-thirds are hired by a new company - several as top executives. Also surprising, the median total compensation change from the new employment is close to zero, suggesting that the rehired CEOs are not particularly "tainted" by the bankruptcy event. The other half of the incumbent CEOs, who do not maintain full-time employment, experience an income loss with a median present value of $\$ 4$ million (discounted until retirement age). This implies an ex ante expected median personal bankruptcy cost of $\$ 2$ million (in constant 2009 dollars).

We also show that CEOs who leave voluntarily suffer lower personal bankruptcy costs than CEOs who are later forced out (typically by creditors). Leaving voluntarily for another full-time employment opportunity leaves the CEO with a median personal bankruptcy cost of zero, while those who find new full-time employment after being forced out suffer a median personal bankruptcy cost of $\$-1.4$ million. A consistent explanation is that CEOs who earn rents prior to bankruptcy prefer to stay until they are forced out, and then take a pay-cut as the wage is being reset to a more competitive level in the new full-time employment opportunity.

Our evidence indicates strongly that creditor activism, in particular through debtor-in-possession (DIP) financing, affects expected CEO personal bankruptcy costs. Creditors take an active interest in which CEO to replace - and with whom. We also find that variables related to CEO employment preference, power, and entrancement affect the probability of CEO being rehired and their personal income loss after departure. When we model the ex ante personal bankruptcy costs, we find that it strongly predicts the decision of CEO voluntary turnover in bankruptcy. 


\section{References}

Ayotte, Kenneth M., and Edward R. Morrison, 2009, Creditor control and conflict in Chapter 11, Journal of Legal Analysis 1, 511-551.

Baird, Douglas G., and Robert K. Rasmussen, 2002, The end of bankruptcy, Stanford Law Review $55,751-790$.

Berk, Jonathan B., Richard Stanton, and Josef Zechner, 2010, Human capital, bankruptcy, and capital structure, Journal of Finance 65, 891-926.

Betker, Brian L., 1995, An empirical examination of prepackaged bankruptcy, Financial Management 24, 3-18.

Borokhvich, Kenneth A., Robert Parrino, and Teresa Trapani, 1996, Outsider directors and CEO selection, Journal of Financial and Quantitative Analysis 31, 337-355.

Branch, Ben S., 2000, Fiduciary duty: Shareholders versus creditors, Financial Practice and Education 10, 8-13.

Coelho, Luis, Richard J. Taffler, and Kose John, 2010, Bankrupt firm: Who's buying?, Working Paper, New York University.

Core, John, and Wayne Guay, 2002, Estimating the value of emploee stock option portfolio and their sensitivities to price and volatility, Journal of Accounting Research 40, 613-630.

Dahiya, Sandeep, Kose John, Manju Puri, and Gabriel Ramirez, 2003, Debtor-in-possession financing and bankruptcy resolution: Empirical evidence, Journal of Financial Economics 69, 259-280.

Denis, David J., and Diane K. Denis, 1995, Causes of financial distress following leveraged recapitalizations, Journal of Financial Economics 37, 129-157.

Eckbo, B. Espen, and Karin S. Thorburn, 2003, Control benefits and CEO discipline in automatic bankruptcy auctions, Journal of Financial Economics 69, 227-258.

Evans, John Harry III, Shuqing Luo, and Nandu J. Nagarajan, 2008, CEO turnover and retention ligt: Retaining former CEOs on the board, Working Paper, University of Pittsburgh.

Evans, John Harry III, Nandu J. Nagarajan, and Jason D. Schloetzer, 2010, CEO turnover and retention ligt: Retaining former CEOs on the board, Journal of Accounting Research 48, 110151047.

Fee, C. Edward, and Charles J. Hadlock, 2004, Management turnover across the corporate hierarchy, Journal of Accounting and Economics 37, 3-38.

Gao, Huasheng, Michael Lemmon, and Kai Li, 2011, A comparison of CEO pay in public and private US firms, Working Paper, University of British Columbia.

Gibbons, Robert, and Kevin J. Murphy, 1992, Optimal incentive contracts in the presence of career concerns: Theory and evidence, Journal of Political Economy 100, 468-505.

Gilson, Stuart C., 1989, Management turnover and financial distress, Journal of Financial Economics 25, 241-262. 
— , 1990, Bankruptcy, boards, banks, and blockholders: Evidence on changes in corporate ownership and control when firms default, Journal of Financial Economics 27, 355-387.

, and Michael R. Vetsuypens, 1993, CEO compensation in financially distressed firms: An empirical analysis, Journal of Finance 48, 425-458.

— 1994, Creditor control in financially distressed firms: The empirical evidence., Washington University Law Quarterly 72, 1005-1025.

Goldman, Eitan, and Peggy Huang, 2011, Contractual versus actual separation pay following CEO turnover, Working Paper, Indiana University and Tulane University.

Hertzel, Michael, Zhi Li, Micah Officer, , and Kimberly Rodgers, 2008, Inter-firm linkages and the wealth effects of financial distress along the supply chain, Journal of Financial Economics 87, $374-387$.

Hirshleifer, David, and Anjan V. Thakor, 1992, Managerial conservatism. project choice, and debt, Review of Financial Studies 5, 437-470.

Hotchkiss, Edith S., 1995, Post-bankruptcy performance and management turnover, Journal of Finance 50, 3-21.

- Kose John, Robert Mooradian, and Karin S. Thorburn, 2008, Bankruptcy and the resolution of financial distress, in B. E. Eckbo, ed.: Handbook of Corporate Finance: Empirical Corporate Finance, vol. 2 . chap. 14, pp. 235-289 (Elsevier/North-Holland, Handbooks in Finance Series).

Huson, Mark R., Paul H. Malatesta, and Robert Parrino, 2004, Managerial succession and firm performance, Journal of Financial Economics 74, 237-275.

Huson, Mark R., Robert Parrino, and Laura Starks, 2001, Internal monitoring mechanism and CEO turnover: A long-term perspective, Journal of Finance 56, 2265-2297.

Jensen, Michael C., and William Meckling, 1976, Theory of the firm: Managerial behavior, agency costs, and capital structure, Journal of Financial Economics 3, 305-360.

Jenter, Dirk, and Fadi Kanaan, 2010, CEO turnover and relative performance evaluation, Journal of Finance forthcoming.

Jiang, Wei, Kai Li, and Wei Wang, 2011, Hedge funds in chapter 11, Journal of Finance forthcoming.

Kang, Q., and Q. A. Mitnik, 2010, CEO power and compensation in financial distressed firms, Working Paper, University of Miami.

Khanna, Naveen, and Annette B. Poulsen, 1995, Managers of financially distressed firms: Vilains or scapegoats?, Journal of Finance 50, 919-940.

Lehn, Ken, and Mengxin Zhao, 2006, CEO turnover after acquisitions: Are bad bidders fired?, Journal of Finance 61, 1759-1811.

Li, Yan, and Anand Srinivasan, 2011, Relationship bank behaviour during borrower distress and bankruptcy, Working Paper, Korea Business School and National University of Singapore. 
Parrino, Robert, 1997, Spinoffs and wealth transfers: The marriott case, Journal of Financial Economics 43, 241-274.

Perez-Gonzales, Francisco, 2006, Inherited control and firm performance, American Economic Review 96, 1559-1588.

Schwab, Stewart J., and Randall S. Thomas, 2004, What do CEO bargain for? An empirical study of key legal components of CEO contracts, Working Paper, Vanderbilt University.

Skeel, David A., 2003, Creditors' ball: The 'new' new corporate governance in Chapter 11, University of Pennsylvania Law Review 152, 917-951.

Yermack, David, 2006, Golden handshakes: Separation pay for retired and dismissed CEOs, Journal of Accounting and Economics 41, 237-256.

Zwiebel, Jeffrey, 1995, Corporate conservatism and relative compensation, Journal of Political Economy 103, 1-25. 


\section{Figure 1}

Mean total CEO pay at old and new firm, classified by new employment type.

Total pay is the sum of salary, bonus and grants. "CEO at old" is the sample of 134 CEOs staying at the old firm. "CEO at private" is the subsample of 70 CEOs becoming CEO at a private company after departure. "CEO at public" is the 28 CEOs becoming CEO of a public company. "Chairman at old" is the 33 CEOs who become board chairman at the old firm after departure. "Executive at private" is the 44 CEOs receiving an executive position (CEO or otherwise) a private company. "Executive at public" is the 52 CEOs receiving an executive position (CEO or otherwise) at a public company. "Other" is the group of 45 CEOs moving to other employment. .

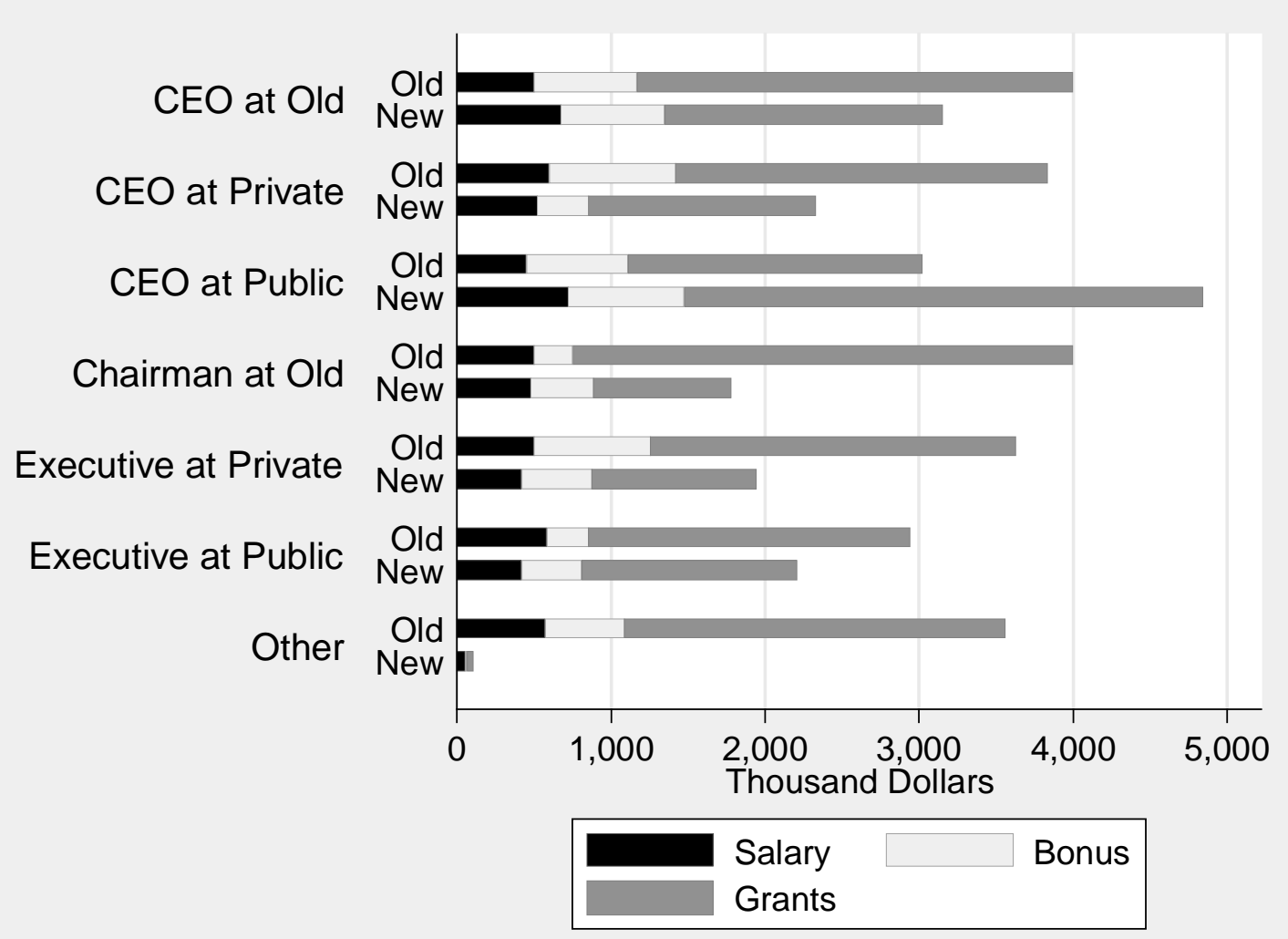




\section{Figure 2}

\section{Histograms of change in CEO total compensation from bankruptcy}

Total compensation is the sum of salary, bonus and grants. All firms were publicly traded before filing for Chapter 11 in the period 1996-2007. All bankruptcy cases were resolved by the beginning of 2011. Not plotted are CEOs who did not maintain full-time employment after bankruptcy (experiencing compensation declines approaching -100\%). As a precaution, the plot also excludes the top five percentile in the distribution of percentage change of total pay.

\section{A. Compensation change for 121 CEOs retaining CEO position at the old firm}

Mean: \$-1,6 mill. Median: \$ -2,0 mill. Standard deviation: \$ 6,7 mill. ; Skewness: -2.16

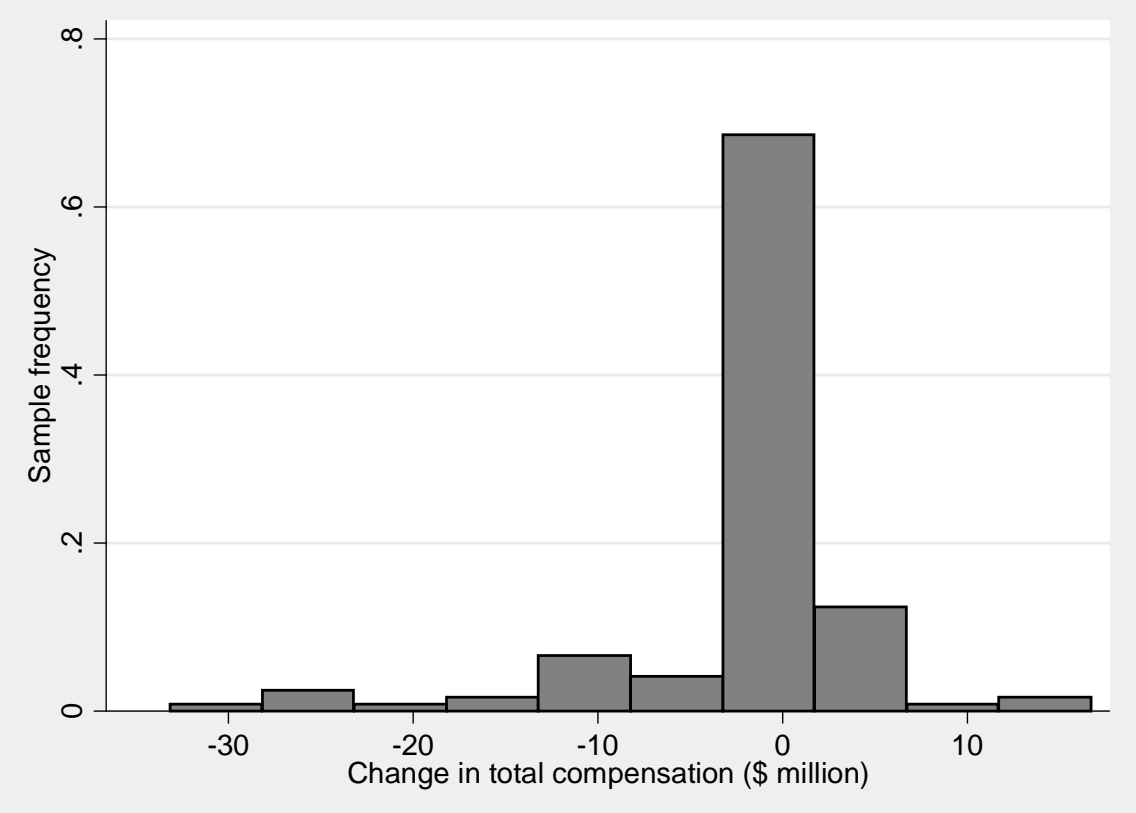

B. Compensation change for 80 CEOs moving to a new CEO position in a public or private firm Mean: \$ -2,4 mill. Median: \$ -0.3 mill. Standard deviation: \$ 7,6 mill. Skewness: -2.97

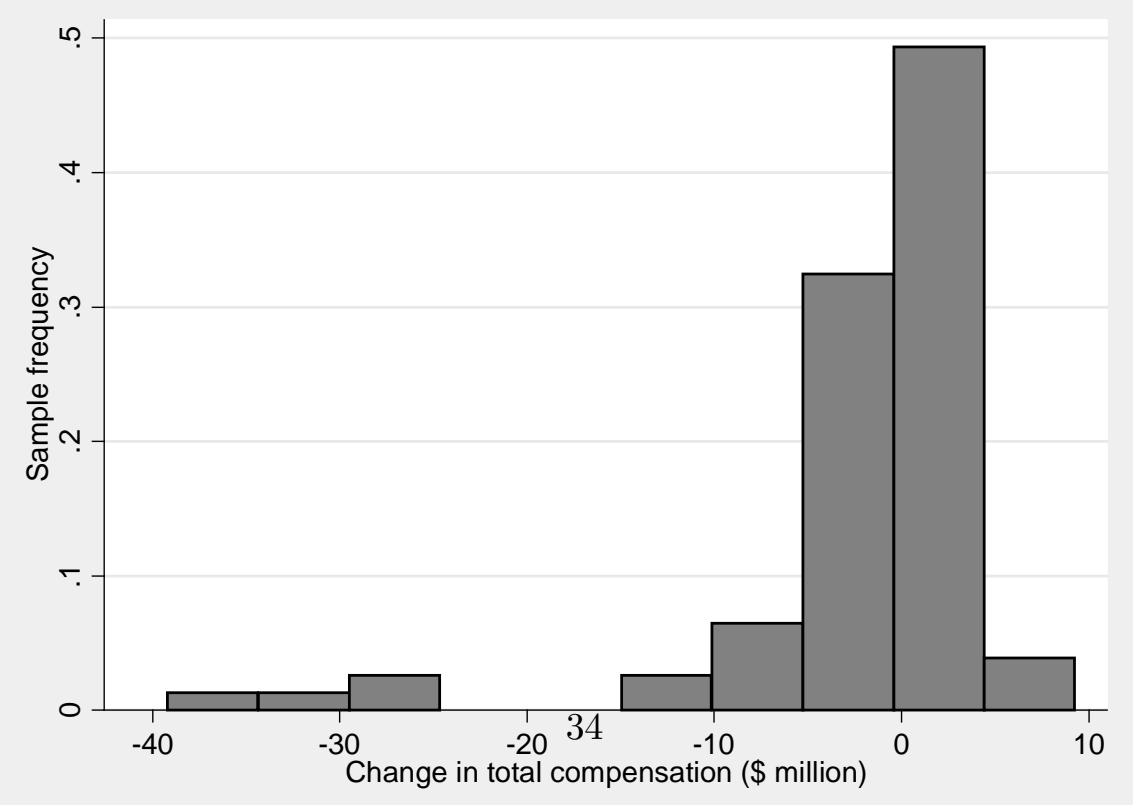




\section{Figure 3}

\section{Index of mean total CEO pay by year relative to Chapter 11 filing (year 0)}

Up through year 0, the graph plots the CEO pay index for the total sample of 342 firms who filed for Chapter 11 during the period 1996-2007 (all cases were resolved by 2011). After year 0, the plot includes firms which emerge from bankruptcy as public companies only. The matching firms are identified in ExecuComp, and are matched on size (sales) and 2-digit industry code. The sample firms filed for Chapter 11 in the period 1996-2007.

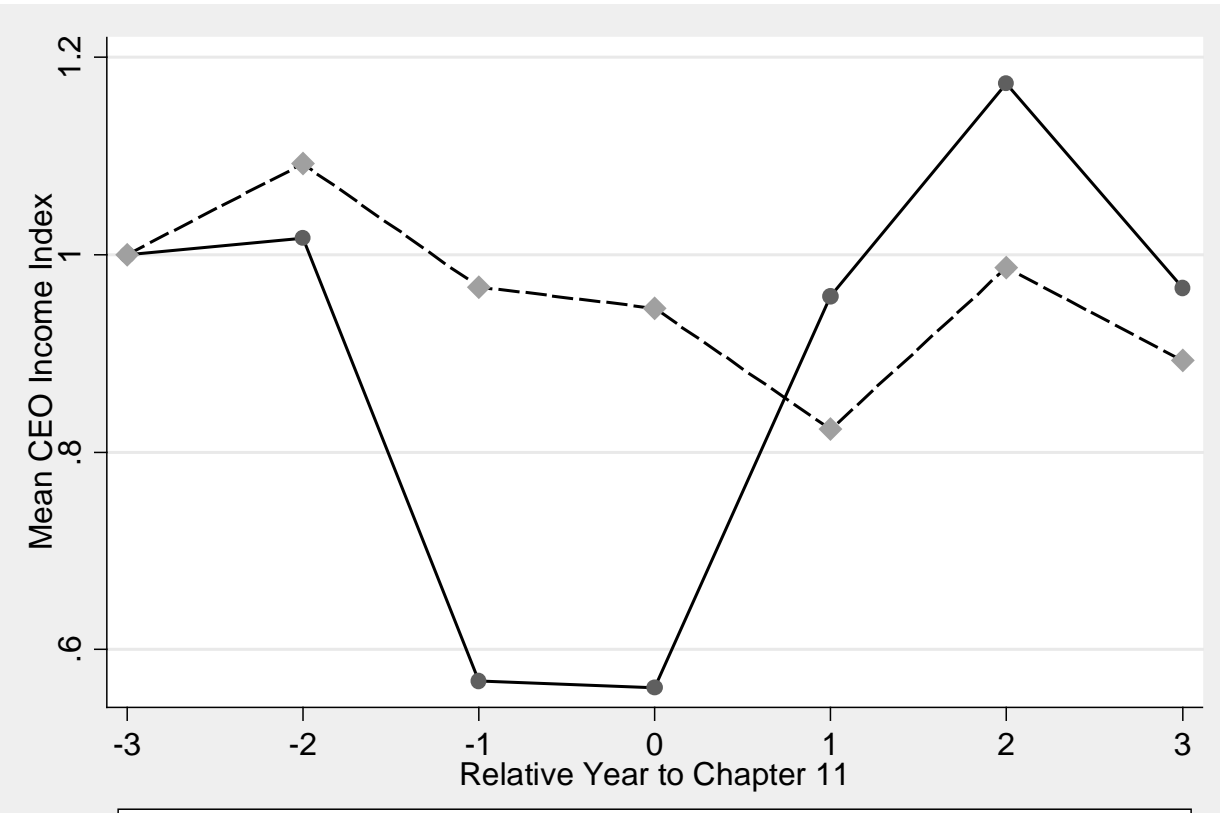

- Total Pay of Sample CEOs - - - - Total Pay of Matching CEOS 


\section{Table 1}

\section{Sample description by year}

The table shows the number of cases and selected sample characteristics by year. The sample is 342 large firms filing for US Chapter 11 bankruptcy in 1996-2007. Sales and assets are in constant 2009 US dollars, and from the last fiscal year prior to filing. All variables are defined in Appendix 1.

\begin{tabular}{|c|c|c|c|c|c|c|c|c|c|c|c|}
\hline \multirow[b]{2}{*}{ Year } & \multirow[b]{2}{*}{$\mathrm{N}$} & \multicolumn{2}{|c|}{$\begin{array}{c}\text { Sales } \\
(\$ \text { mill. })\end{array}$} & \multicolumn{2}{|c|}{$\begin{array}{l}\text { Assets } \\
\text { (\$ mill.) }\end{array}$} & \multicolumn{2}{|c|}{$\begin{array}{l}\text { Duration } \\
\text { (months) }\end{array}$} & \multirow{2}{*}{$\frac{\text { Prepack }}{(\%)}$} & \multicolumn{3}{|c|}{$\begin{array}{c}\text { Bankruptcy } \\
\text { outcome (\%) }\end{array}$} \\
\hline & & mean & median & mean & median & mean & median & & $\begin{array}{l}\text { Emer- } \\
\text { gence }\end{array}$ & $\begin{array}{l}\text { Liqui- } \\
\text { dation }\end{array}$ & $\begin{array}{l}\text { Acqui- } \\
\text { sition }\end{array}$ \\
\hline 1996 & 7 & 1,972 & 832 & 829 & 593 & 8.5 & 4.5 & 43 & 43 & 43 & 14 \\
\hline 1997 & 14 & 1,551 & 627 & 1,206 & 462 & 21.6 & 12.9 & 36 & 86 & 14 & 0 \\
\hline 1998 & 26 & 715 & 389 & 736 & 500 & 19.1 & 13.3 & 27 & 65 & 27 & 8 \\
\hline 1999 & 33 & 1,311 & 666 & 1,646 & 888 & 15.9 & 8.6 & 39 & 61 & 33 & 6 \\
\hline 2000 & 56 & 1,341 & 684 & 1,386 & 582 & 21.8 & 18.1 & 21 & 57 & 29 & 14 \\
\hline 2001 & 63 & 3,770 & 768 & 3,873 & 1103 & 17.1 & 12.7 & 17 & 54 & 35 & 11 \\
\hline 2002 & 57 & 3,666 & 988 & 6,976 & 1067 & 13.1 & 8.9 & 46 & 63 & 19 & 18 \\
\hline 2003 & 36 & 1,077 & 729 & 2,028 & 741 & 16.0 & 10.0 & 31 & 75 & 17 & 8 \\
\hline 2004 & 16 & 1,381 & 561 & 1,585 & 766 & 12.2 & 10.2 & 38 & 88 & 13 & 0 \\
\hline 2005 & 17 & 5,854 & 1,017 & 9,194 & 770 & 17.7 & 16.7 & 12 & 71 & 18 & 12 \\
\hline 2006 & 8 & 1,964 & 990 & 1,660 & 477 & 9.3 & 5.6 & 63 & 100 & 0 & 0 \\
\hline 2007 & 9 & 22,329 & 545 & 4,178 & 705 & 10.2 & 11.6 & 33 & 44 & 56 & 0 \\
\hline Total & 342 & 2,912 & 739 & 3,278 & 798 & 16.6 & 12.7 & 30 & 64 & 26 & 10 \\
\hline
\end{tabular}


Table 2

CEO turnover, age, and tenure by relative year

The table shows CEO turnover and the average age and tenure of the departing CEOs by year relative to bankruptcy filing, where the year of filing is 0. The sample is 342 large firms filing for US Chapter 11 in 1996-2007. The CEO data starts three years prior to filing and ends three years after emergence or when the firm is liquidated, and spans from year 1993 through 2010. Year 4+ includes year 4 through the end of our sample. The information on the departing CEO is incomplete in 57 cases where a new CEO is hired in the first year that the firm enters our sample. All variables are defined in Appendix 1.

\section{A: Year relative to Chapter 11 filing}

\begin{tabular}{|c|c|c|c|c|c|c|c|c|c|}
\hline \multirow{2}{*}{$\begin{array}{l}\text { Year } \\
\text { rel. to } \\
\text { filing }\end{array}$} & \multirow[b]{2}{*}{$N$} & \multicolumn{2}{|c|}{$\begin{array}{c}\text { CEO } \\
\text { turnover }\end{array}$} & \multicolumn{3}{|c|}{ Departing CEOs } & \multicolumn{2}{|c|}{$\begin{array}{c}\text { Forced } \\
\text { turnover }\end{array}$} & \multirow{2}{*}{$\begin{array}{c}\% \text { of original } \\
\text { CEOs departed } \\
\text { at year-end }\end{array}$} \\
\hline & & $N$ & $\%$ & $N$ & Age & Tenure & $N$ & $\%$ & \\
\hline-3 & 308 & 46 & 15 & - & - & - & - & - & 0 \\
\hline-2 & 335 & 66 & 20 & 60 & 54.5 & 5.0 & 19 & 32 & 20 \\
\hline-1 & 342 & 88 & 26 & 83 & 54.4 & 5.0 & 40 & 48 & 41 \\
\hline 0 & 342 & 100 & 29 & 100 & 52.9 & 3.9 & 56 & 56 & 56 \\
\hline 1 & 341 & 113 & 33 & 113 & 54.3 & 4.8 & 62 & 55 & 71 \\
\hline 2 & 247 & 75 & 30 & 75 & 54.7 & 5.9 & 46 & 61 & 81 \\
\hline 3 & 138 & 30 & 22 & 30 & 57.0 & 4.2 & 11 & 37 & 84 \\
\hline $4+$ & 144 & 13 & 9 & 13 & 53.2 & 6.5 & 7 & 54 & - \\
\hline Total & 2,197 & 531 & 24 & 474 & 54.2 & 4.8 & 241 & 51 & - \\
\hline
\end{tabular}

\section{B: Reason for turnover}

\begin{tabular}{|c|c|c|}
\hline All turnover & Forced & Voluntary \\
\hline$\%$ & $\%$ & $\%$ \\
\hline
\end{tabular}

Resigned for personal reasons

Pursue other interest

Pressured by the board, shareholders, creditors

Performance related

Liquidation or acquisition

Retirement or normal succession

Death or illness

Other reasons

No reason given

\begin{tabular}{cccccc}
99 & 21 & 45 & 45 & 54 & 55 \\
56 & 12 & 26 & 46 & 30 & 54 \\
63 & 13 & 63 & 100 & 0 & 0 \\
17 & 4 & 17 & 100 & 0 & 0 \\
91 & 19 & 63 & 69 & 28 & 31 \\
70 & 15 & 0 & 0 & 70 & 100 \\
2 & 0 & 0 & 0 & 2 & 100 \\
27 & 6 & 0 & 0 & 27 & 100 \\
49 & 10 & 27 & 55 & 22 & 45 \\
& & & & & \\
474 & 100 & 241 & 51 & 233 & 49 \\
& & & & & \\
\hline
\end{tabular}


Table 3

\section{CEO new employment after departure}

The table shows the new employment of the departed CEO (Panel A) and the size of the new firm where she is employed (Panel B). The sample is 474 CEOs that left their position between year -2 (where 0 is the year of filing) and three years after emergence at 342 large firms filing for US Chapter 11 in 1996-2007. All variables are defined in Appendix 1. The p-value is from a Wilcoxon test of the difference in median between old and new firms, limited to cases with data on both firms.

\section{A: CEO new employment after departure}

\begin{tabular}{|c|c|c|c|c|c|c|c|}
\hline & \multicolumn{2}{|c|}{$\begin{array}{c}\text { All } \\
\text { departures }\end{array}$} & \multicolumn{2}{|c|}{ Forced } & \multicolumn{2}{|c|}{ Voluntary } & \multirow{2}{*}{$\begin{array}{l}\text { Years to } \\
\text { new job } \\
\text { mean }\end{array}$} \\
\hline & $\mathrm{N}$ & $\%$ & $\mathrm{~N}$ & $\%$ & $\mathrm{~N}$ & $\%$ & \\
\hline Stay as chairman & 33 & 7 & 3 & 9 & 30 & 91 & 0.0 \\
\hline Retain honorary position at old firm & 46 & 10 & 12 & 26 & 34 & 74 & 0.0 \\
\hline CEO at a public company & 28 & 6 & 15 & 54 & 13 & 46 & 1.3 \\
\hline $\mathrm{CEO}$ at a private company & 70 & 15 & 44 & 63 & 26 & 37 & 1.4 \\
\hline Non-CEO executive at a public company & 52 & 11 & 19 & 37 & 33 & 63 & 1.2 \\
\hline Non-CEO executive at a private company & 44 & 9 & 16 & 36 & 28 & 64 & 1.2 \\
\hline Consultant or politician & 19 & 4 & 7 & 37 & 12 & 63 & 1.1 \\
\hline Self-employed & 26 & 5 & 17 & 65 & 9 & 35 & 1.3 \\
\hline No new employment & 156 & 33 & 108 & 69 & 48 & 31 & - \\
\hline All departed CEOs & 474 & 100 & 241 & 100 & 233 & 100 & 1.0 \\
\hline
\end{tabular}

B: Industry and sales (in \$ million) of firms that hire departed CEOs

\begin{tabular}{ccccccc}
\multicolumn{2}{c}{$\begin{array}{c}\% \text { firms } \\
\text { in same }\end{array}$} & \multicolumn{2}{c}{$\begin{array}{c}\text { Old firm } \\
\text { sales }\end{array}$} & & \multicolumn{2}{c}{$\begin{array}{c}\text { New firm } \\
\text { sales }\end{array}$} \\
\cline { 3 - 3 }$N$ & industry & $N$ & median & & median & p-value \\
\hline
\end{tabular}

Type of new position:

CEO at a private company $\quad 70 \quad 29$

Non-CEO executive at a public company $\quad 52 \quad 25$

Non-CEO executive at a private company $\quad 44 \quad 29$

\begin{tabular}{|c|c|c|c|c|}
\hline All departed CEOs employed at a new firm & 194 & 29 & 142 & 1,066 \\
\hline
\end{tabular}


Table 4

New employment types by relative year, age, and reason for departure

The table shows the percent new employment types for departing CEOs by departure year relative to bankruptcy filing (Panel A), by age (Panel B), and by reason for CEO departure (Panel C), respectively. The sample is 474 CEOs that left their position between year -2 (where 0 is the year of filing) and three years after emergence at 342 large US firms filing for Chapter 11 in 1996-2007. All variables are defined in Appendix 1.

\begin{tabular}{|c|c|c|c|c|c|c|c|c|}
\hline & \multicolumn{8}{|c|}{ Type of new employment: } \\
\hline & $\begin{array}{c}\text { Stay as } \\
\text { chair- } \\
\text { man }\end{array}$ & $\begin{array}{c}\text { Retain } \\
\text { honorary } \\
\text { position }\end{array}$ & $\begin{array}{c}\text { CEO at } \\
\text { a new } \\
\text { firm }\end{array}$ & $\begin{array}{c}\text { Non- } \\
\text { CEO } \\
\text { executive }\end{array}$ & $\begin{array}{c}\text { Consultant } \\
\text { or } \\
\text { politician }\end{array}$ & $\begin{array}{l}\text { Self- } \\
\text { empl. }\end{array}$ & $\begin{array}{c}\text { No } \\
\text { new } \\
\text { empl. }\end{array}$ & Total \\
\hline All & 7 & 10 & 21 & 20 & 4 & 5 & 33 & 100 \\
\hline \multicolumn{9}{|c|}{ A: CEO new employment by year of departure relative to bankruptcy filing } \\
\hline-2 & 17 & 17 & 15 & 22 & 2 & 7 & 22 & 100 \\
\hline-1 & 7 & 12 & 16 & 22 & 2 & 4 & 37 & 100 \\
\hline 0 & 10 & 10 & 25 & 16 & 2 & 2 & 35 & 100 \\
\hline 1 & 2 & 10 & 19 & 19 & 4 & 11 & 36 & 100 \\
\hline 2 & 3 & 4 & 28 & 27 & 3 & 4 & 32 & 100 \\
\hline 3 & 7 & 3 & 23 & 17 & 3 & 7 & 40 & 100 \\
\hline $4+$ & 8 & 8 & 15 & 15 & 8 & 0 & 46 & 100 \\
\hline \multicolumn{9}{|c|}{ B: CEO new employment by age at departure } \\
\hline Less than 50 years old & 7 & 7 & 29 & 27 & 2 & 4 & 23 & 100 \\
\hline $51-60$ years old & 5 & 12 & 18 & 20 & 3 & 4 & 37 & 100 \\
\hline More than 60 years old & 12 & 10 & 15 & 11 & 1 & 5 & 45 & 100 \\
\hline \multicolumn{9}{|c|}{ C: CEO new employment by reason for departure } \\
\hline Resigned for personal reasons & 9 & 15 & 20 & 21 & 4 & 4 & 26 & 100 \\
\hline Pursue other interests & 4 & 4 & 29 & 30 & 2 & 9 & 23 & 100 \\
\hline $\begin{array}{l}\text { Pressured by the board, } \\
\text { shareholders, or creditors }\end{array}$ & 5 & 11 & 22 & 11 & 3 & 6 & 41 & 100 \\
\hline Performance related & 0 & 18 & 24 & 24 & 0 & 0 & 35 & 100 \\
\hline Liquidation or acquisition & 0 & 4 & 19 & 25 & 3 & 8 & 41 & 100 \\
\hline Retirement or normal succession & 10 & 6 & 10 & 19 & 3 & 3 & 50 & 100 \\
\hline Death or illness & 0 & 50 & 0 & 0 & 0 & 0 & 50 & 100 \\
\hline Other reasons & 11 & 15 & 30 & 19 & 0 & 7 & 19 & 100 \\
\hline No reason given & 18 & 12 & 24 & 12 & 2 & 4 & 27 & 100 \\
\hline
\end{tabular}


Table 5

\section{Characteristics of the new CEOs}

The sample is 394 new CEOs that were hired during our sample period, year -3 (where 0 is the year of filing) to three years after emergence at 342 large US firms filing for Chapter 11 in 1996-2007. All variables are defined in Appendix 1.

\section{A: Characteristics of new CEOs by hiring year}

\begin{tabular}{|c|c|c|c|c|c|}
\hline Year relative to bankruptcy & $N$ & $\begin{array}{c}\% \\
\text { External }\end{array}$ & $\begin{array}{c}\% \\
\text { Specialist }\end{array}$ & $\begin{array}{c}\% \text { with } \\
\text { prior CEO } \\
\text { experience }\end{array}$ & $\begin{array}{c}\text { Age } \\
\text { (mean) }\end{array}$ \\
\hline-3 & 46 & 50 & 4 & 39 & 50.1 \\
\hline-2 & 66 & 55 & 15 & 32 & 50.2 \\
\hline-1 & 88 & 55 & 15 & 40 & 52.6 \\
\hline 0 & 100 & 59 & 28 & 45 & 52.1 \\
\hline 1 & 49 & 67 & 22 & 43 & 51.9 \\
\hline 2 & 26 & 62 & 19 & 54 & 52.8 \\
\hline 3 & 15 & 60 & 13 & 53 & 53.6 \\
\hline 4 & 4 & 25 & 0 & 0 & 53.5 \\
\hline All & 394 & 57 & 18 & 41 & 51.7 \\
\hline
\end{tabular}

\section{B: Average characteristics of new CEOs hired externally}

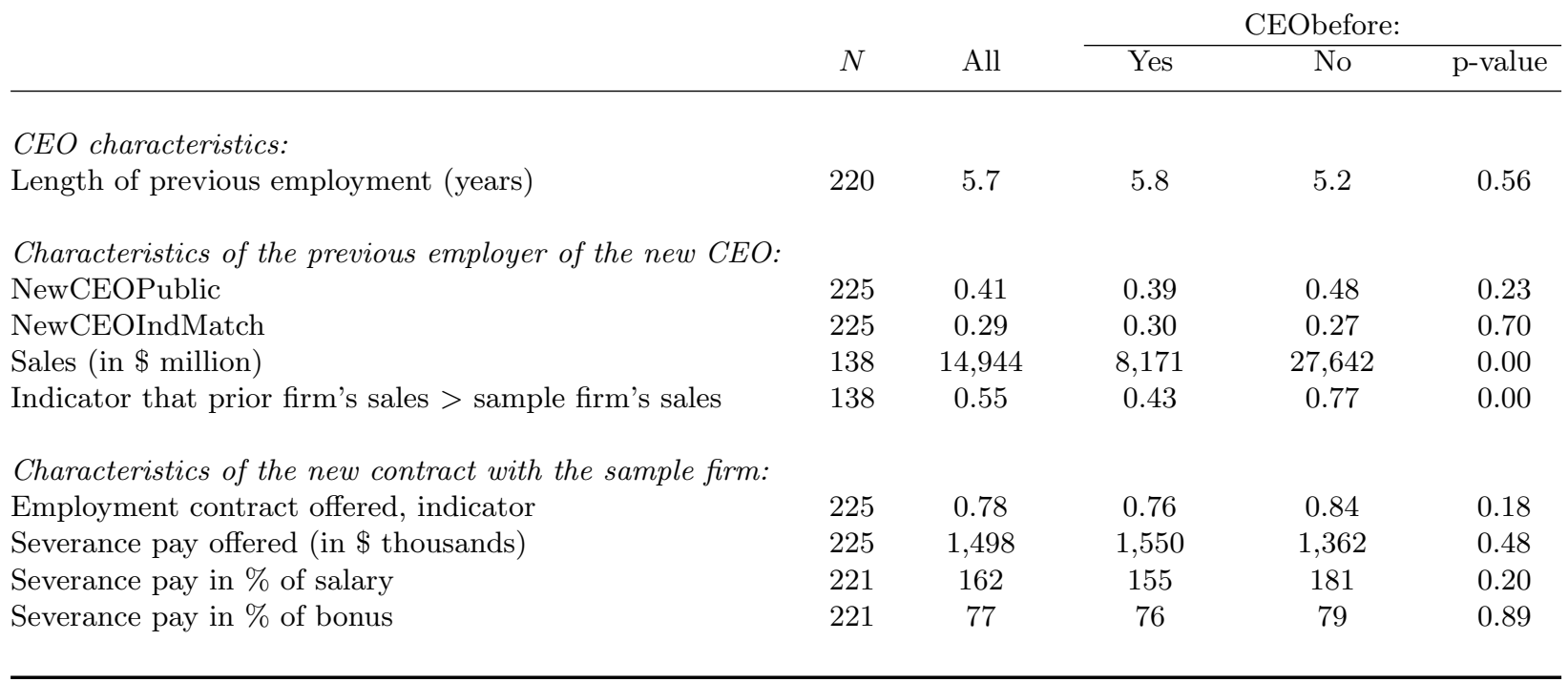




\section{Table 6 \\ Regressions for the probability of forced and voluntary turnover}

The table shows the coefficient estimates from multinomial logit regressions for the probability of CEO turnover. All models have three outcomes: no turnover, voluntary turnover, and forced turnover. The sample is 1,625 firm-years from year -3 to 3 years after emergence or liquidation for 342 large firms filing for US Chapter 11 bankruptcy in 1996-2007. All regressions control for industry fixed effects at the 2-digit SIC code level. Standard errors are in brackets. ${ }^{* * *},{ }^{* *}$, and ${ }^{*}$ denotes significance at the $1 \%, 5 \%$ and $10 \%$ level, respectively. All variables are defined in Appendix 1.

\begin{tabular}{|c|c|c|c|c|c|c|c|c|}
\hline & \multicolumn{2}{|c|}{ 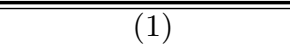 } & \multicolumn{2}{|c|}{$\overline{(2)}$} & \multicolumn{2}{|c|}{$\overline{(3)}$} & \multicolumn{2}{|c|}{$\overline{(4)}$} \\
\hline & Voluntary & Forced & Voluntary & Forced & Voluntary & Forced & Voluntary & Forced \\
\hline Intercept & $\begin{array}{c}-28.945^{* * *} \\
{[1.510]}\end{array}$ & $\begin{array}{l}-2.294 \\
{[1.715]}\end{array}$ & $\begin{array}{c}-28.875^{* * *} \\
{[1.502]}\end{array}$ & $\begin{array}{l}-2.280 \\
{[1.613]}\end{array}$ & $\begin{array}{c}-29.216^{* * *} \\
{[1.519]}\end{array}$ & $\begin{array}{l}-2.673 \\
{[1.636]}\end{array}$ & $\begin{array}{c}-28.990^{* * *} \\
{[1.538]}\end{array}$ & $\begin{array}{l}-2.390 \\
{[1.799]}\end{array}$ \\
\hline \multicolumn{9}{|l|}{ Relative years: } \\
\hline Before & $\begin{array}{c}0.322 \\
{[0.332]}\end{array}$ & $\begin{array}{c}0.041 \\
{[0.418]}\end{array}$ & $\begin{array}{c}0.299 \\
{[0.282]}\end{array}$ & $\begin{array}{l}-0.300 \\
{[0.393]}\end{array}$ & $\begin{array}{c}0.168 \\
{[0.302]}\end{array}$ & $\begin{array}{l}-0.057 \\
{[0.390]}\end{array}$ & $\begin{array}{c}0.346 \\
{[0.373]}\end{array}$ & $\begin{array}{c}0.278 \\
{[0.472]}\end{array}$ \\
\hline During & $\begin{array}{c}0.689^{* * *} \\
{[0.261]}\end{array}$ & $\begin{array}{c}1.498^{* * *} \\
{[0.293]}\end{array}$ & $\begin{array}{c}0.615^{* *} \\
{[0.245]}\end{array}$ & $\begin{array}{c}1.412^{* * *} \\
{[0.286]}\end{array}$ & $\begin{array}{c}0.773^{* * *} \\
{[0.256]}\end{array}$ & $\begin{array}{c}1.532^{* * *} \\
{[0.297]}\end{array}$ & $\begin{array}{c}0.742^{* *} \\
{[0.291]}\end{array}$ & $\begin{array}{c}1.843^{* * *} \\
{[0.317]}\end{array}$ \\
\hline \multicolumn{9}{|l|}{ CEO characteristics: } \\
\hline Age & $\begin{array}{c}0.057^{* * *} \\
{[0.012]}\end{array}$ & $\begin{array}{c}0.001 \\
{[0.013]}\end{array}$ & $\begin{array}{c}0.053^{* * *} \\
{[0.012]}\end{array}$ & $\begin{array}{c}0.003 \\
{[0.013]}\end{array}$ & $\begin{array}{c}0.054^{* * *} \\
{[0.012]}\end{array}$ & $\begin{array}{c}0.004 \\
{[0.013]}\end{array}$ & $\begin{array}{c}0.059^{* * *} \\
{[0.013]}\end{array}$ & $\begin{array}{l}-0.001 \\
{[0.013]}\end{array}$ \\
\hline Tenure & $\begin{array}{l}-0.009 \\
{[0.024]}\end{array}$ & $\begin{array}{l}0.045^{*} \\
{[0.024]}\end{array}$ & $\begin{array}{l}-0.017 \\
{[0.023]}\end{array}$ & $\begin{array}{c}0.028 \\
{[0.022]}\end{array}$ & $\begin{array}{l}-0.017 \\
{[0.023]}\end{array}$ & $\begin{array}{c}0.024 \\
{[0.022]}\end{array}$ & $\begin{array}{l}-0.014 \\
{[0.024]}\end{array}$ & $\begin{array}{l}0.045^{*} \\
{[0.024]}\end{array}$ \\
\hline Chairman & $\begin{array}{c}0.152 \\
{[0.183]}\end{array}$ & $\begin{array}{c}0.109 \\
{[0.199]}\end{array}$ & $\begin{array}{c}0.135 \\
{[0.179]}\end{array}$ & $\begin{array}{c}0.117 \\
{[0.195]}\end{array}$ & $\begin{array}{c}0.133 \\
{[0.179]}\end{array}$ & $\begin{array}{c}0.173 \\
{[0.194]}\end{array}$ & $\begin{array}{c}0.149 \\
{[0.185]}\end{array}$ & $\begin{array}{c}0.092 \\
{[0.202]}\end{array}$ \\
\hline Ownpct & $\begin{array}{c}-0.044^{* * *} \\
{[0.013]}\end{array}$ & $\begin{array}{l}-0.012 \\
{[0.009]}\end{array}$ & $\begin{array}{c}-0.034^{* * *} \\
{[0.012]}\end{array}$ & $\begin{array}{l}-0.011 \\
{[0.009]}\end{array}$ & $\begin{array}{c}-0.033^{* * *} \\
{[0.012]}\end{array}$ & $\begin{array}{l}-0.014 \\
{[0.009]}\end{array}$ & $\begin{array}{c}-0.043^{* * *} \\
{[0.013]}\end{array}$ & $\begin{array}{l}-0.011 \\
{[0.009]}\end{array}$ \\
\hline \multicolumn{9}{|l|}{ Firm characteristics: } \\
\hline Size & $\begin{array}{c}0.092 \\
{[0.074]}\end{array}$ & $\begin{array}{c}0.033 \\
{[0.072]}\end{array}$ & $\begin{array}{c}0.110 \\
{[0.072]}\end{array}$ & $\begin{array}{l}-0.015 \\
{[0.063]}\end{array}$ & $\begin{array}{c}0.157^{* *} \\
{[0.072]}\end{array}$ & $\begin{array}{c}0.017 \\
{[0.065]}\end{array}$ & $\begin{array}{c}0.101 \\
{[0.079]}\end{array}$ & $\begin{array}{c}0.002 \\
{[0.075]}\end{array}$ \\
\hline $\mathrm{ROA}$ & $\begin{array}{l}-0.641 \\
{[0.831]}\end{array}$ & $\begin{array}{c}-1.383^{*} \\
{[0.732]}\end{array}$ & $\begin{array}{l}-0.381 \\
{[0.823]}\end{array}$ & $\begin{array}{c}-1.311^{*} \\
{[0.719]}\end{array}$ & $\begin{array}{l}-0.375 \\
{[0.833]}\end{array}$ & $\begin{array}{c}-1.340^{*} \\
{[0.716]}\end{array}$ & $\begin{array}{l}-0.549 \\
{[0.865]}\end{array}$ & $\begin{array}{c}-1.660^{* *} \\
{[0.753]}\end{array}$ \\
\hline Leverage & $\begin{array}{c}0.029 \\
{[0.211]}\end{array}$ & $\begin{array}{l}0.319^{*} \\
{[0.184]}\end{array}$ & $\begin{array}{l}-0.007 \\
{[0.213]}\end{array}$ & $\begin{array}{l}0.312^{*} \\
{[0.183]}\end{array}$ & $\begin{array}{c}0.005 \\
{[0.216]}\end{array}$ & $\begin{array}{c}0.417^{* *} \\
{[0.187]}\end{array}$ & $\begin{array}{l}-0.039 \\
{[0.228]}\end{array}$ & $\begin{array}{l}0.354^{*} \\
{[0.194]}\end{array}$ \\
\hline Tangibility & $\begin{array}{l}-0.021 \\
{[0.555]}\end{array}$ & $\begin{array}{c}-0.33 \\
{[0.570]}\end{array}$ & $\begin{array}{l}-0.056 \\
{[0.550]}\end{array}$ & $\begin{array}{c}-0.29 \\
{[0.551]}\end{array}$ & $\begin{array}{l}-0.152 \\
{[0.554]}\end{array}$ & $\begin{array}{l}-0.372 \\
{[0.560]}\end{array}$ & $\begin{array}{l}-0.057 \\
{[0.564]}\end{array}$ & $\begin{array}{l}-0.453 \\
{[0.578]}\end{array}$ \\
\hline Investors & & & & & & & & \\
\hline Before $\times$ Large institution & $\begin{array}{l}-0.186 \\
{[0.365]}\end{array}$ & $\begin{array}{l}-0.849 \\
{[0.563]}\end{array}$ & & & & & $\begin{array}{l}-0.134 \\
{[0.372]}\end{array}$ & $\begin{array}{c}-1.023^{*} \\
{[0.569]}\end{array}$ \\
\hline During $\times$ large institution & $\begin{array}{l}-0.068 \\
{[0.251]}\end{array}$ & $\begin{array}{c}-0.479^{* *} \\
{[0.242]}\end{array}$ & & & & & $\begin{array}{l}-0.112 \\
{[0.255]}\end{array}$ & $\begin{array}{c}-0.551^{* *} \\
{[0.245]}\end{array}$ \\
\hline Bank le & & & & & & & & \\
\hline Before $\times$ Large bank loan & & & $\begin{array}{l}-1.069 \\
{[0.762]}\end{array}$ & $\begin{array}{c}0.166 \\
{[0.607]}\end{array}$ & & & $\begin{array}{l}-0.958 \\
{[0.781]}\end{array}$ & $\begin{array}{c}0.115 \\
{[0.640]}\end{array}$ \\
\hline During $\times$ Large bank loan & & & $\begin{array}{c}0.494 \\
{[0.331]}\end{array}$ & $\begin{array}{l}-0.366 \\
{[0.324]}\end{array}$ & & & $\begin{array}{c}0.378 \\
{[0.368]}\end{array}$ & $\begin{array}{l}-0.528 \\
{[0.346]}\end{array}$ \\
\hline DIP & & & $\begin{array}{c}0.234 \\
{[0.203]}\end{array}$ & $\begin{array}{c}0.587^{* * *} \\
{[0.214]}\end{array}$ & & & $\begin{array}{l}0.361^{*} \\
{[0.211]}\end{array}$ & $\begin{array}{c}0.588^{* * *} \\
{[0.223]}\end{array}$ \\
\hline Unsec & & & & & & & & \\
\hline Before $\times$ Large bond liability & & & & & $\begin{array}{l}0.834^{*} \\
{[0.476]}\end{array}$ & $\begin{array}{l}-0.943 \\
{[1.063]}\end{array}$ & $\begin{array}{c}0.757 \\
{[0.494]}\end{array}$ & $\begin{array}{l}-0.001 \\
{[1.105]}\end{array}$ \\
\hline During $\times$ Large bond liability & & & & & $\begin{array}{l}-0.064 \\
{[0.399]}\end{array}$ & $\begin{array}{c}-0.31 \\
{[0.340]}\end{array}$ & $\begin{array}{c}0.08 \\
{[0.415]}\end{array}$ & $\begin{array}{l}-0.434 \\
{[0.361]}\end{array}$ \\
\hline Before $\times$ Large nondebt liability & & & & & $\begin{array}{l}-0.612 \\
{[0.593]}\end{array}$ & $\begin{array}{l}-0.211 \\
{[0.789]}\end{array}$ & $\begin{array}{l}-0.701 \\
{[0.602]}\end{array}$ & $\begin{array}{l}-0.183 \\
{[0.812]}\end{array}$ \\
\hline During $\times$ Large nondebt liability & & & & & $\begin{array}{c}-0.4 \\
{[0.310]}\end{array}$ & $\begin{array}{c}-0.567^{* *} \\
{[0.287]}\end{array}$ & $\begin{array}{l}-0.328 \\
{[0.322]}\end{array}$ & $\begin{array}{c}-0.774^{* * *} \\
{[0.300]}\end{array}$ \\
\hline Prepack & $\begin{array}{l}-0.085 \\
{[0.361]}\end{array}$ & $\begin{array}{l}-0.270 \\
{[0.334]}\end{array}$ & $\begin{array}{l}-9.166 \\
40.359\end{array}$ & $\begin{array}{l}-0.342 \\
{[0.341]}\end{array}$ & $\begin{array}{l}-0.135 \\
{[0.362]}\end{array}$ & $\begin{array}{l}-0.380 \\
{[0.341]}\end{array}$ & $\begin{array}{l}-0.168 \\
{[0.371]}\end{array}$ & $\begin{array}{r}-0.400 \\
{[0.350]}\end{array}$ \\
\hline $\mathrm{N}$ & 1,5 & & 1,6 & & 1,6 & & & \\
\hline $\begin{array}{l}\text { of which } \mathrm{N} \text { (volunt) and } \mathrm{N} \text { (forced) } \\
\text { Pseudo } R^{2}\end{array}$ & 165 & $25^{161}$ & ${ }_{0.1}^{168}$ & $23^{163}$ & ${ }_{0.1}^{168}$ & 21 & ${ }^{164} 0.1$ & $40^{160}$ \\
\hline
\end{tabular}




\section{Table 7 \\ Regressions for the probability of internal and of external succession}

The table shows the coefficient estimates from multinomial logit regressions for the probability of internal and external succession of the departed CEO. All models have three outcomes: no turnover, internal succession, and external succession. The sample is 1,654 firm-years from year -3 to 3 years after emergence or liquidation for 342 large firms filing for US Chapter 11 bankruptcy in 1996-2007. All regressions control for industry fixed effects at the 2-digit SIC code level. Standard errors are in brackets. ${ }^{* * *}{ }^{* *}$, and ${ }^{*}$ denotes significance at the $1 \%, 5 \%$ and $10 \%$ level, respectively. All variables are defined in Appendix 1.

\begin{tabular}{|c|c|c|c|c|c|c|c|c|}
\hline & \multicolumn{2}{|c|}{ 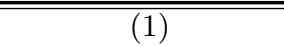 } & \multicolumn{2}{|c|}{ 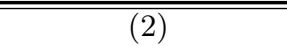 } & \multicolumn{2}{|c|}{ 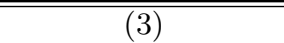 } & \multicolumn{2}{|c|}{$\overline{(4)}$} \\
\hline & Internal & External & I Internal & External & Internal & External & Internal & External \\
\hline Intercept & $\begin{array}{c}-27.746^{* * *} \\
{[1.561]}\end{array}$ & $\begin{array}{c}-4.158^{* *} \\
{[1.628]}\end{array}$ & $\begin{array}{c}-27.734^{* * *} \\
{[1.546]}\end{array}$ & $\begin{array}{c}-3.882^{* *} \\
{[1.514]}\end{array}$ & $\begin{array}{c}-28.262^{* * *} \\
{[1.551]}\end{array}$ & $\begin{array}{c}-4.325^{* * *} \\
{[1.539]}\end{array}$ & $\begin{array}{c}-27.935^{* * *} \\
{[1.576]}\end{array}$ & $\begin{array}{c}-4.366^{* * *} \\
{[1.655]}\end{array}$ \\
\hline \multicolumn{9}{|l|}{ Relative years: } \\
\hline Before & $\begin{array}{c}1.110^{* * *} \\
{[0.365]}\end{array}$ & $\begin{array}{l}0.574^{*} \\
{[0.325]}\end{array}$ & $\begin{array}{c}0.912^{* * *} \\
{[0.335]}\end{array}$ & $\begin{array}{c}0.34 \\
{[0.295]}\end{array}$ & $\begin{array}{c}0.914^{* * *} \\
{[0.349]}\end{array}$ & $\begin{array}{c}0.349 \\
{[0.306]}\end{array}$ & $\begin{array}{c}1.183^{* * *} \\
{[0.402]}\end{array}$ & $\begin{array}{l}0.671^{*} \\
{[0.368]}\end{array}$ \\
\hline During & $\begin{array}{c}1.347^{* * *} \\
{[0.321]}\end{array}$ & $\begin{array}{c}1.222^{* * *} \\
{[0.259]}\end{array}$ & $\begin{array}{c}1.480^{* * *} \\
{[0.303]}\end{array}$ & $\begin{array}{c}0.979^{* * *} \\
{[0.251]}\end{array}$ & $\begin{array}{c}1.632^{* * *} \\
{[0.314]}\end{array}$ & $\begin{array}{c}1.196^{* * *} \\
{[0.260]}\end{array}$ & $\begin{array}{c}1.664^{* * *} \\
{[0.343]}\end{array}$ & $\begin{array}{l}1.37^{* * *} \\
{[0.285]}\end{array}$ \\
\hline \multicolumn{9}{|l|}{ CEO characteristics: } \\
\hline Age & $\begin{array}{c}0.036^{* * *} \\
{[0.013]}\end{array}$ & $\begin{array}{c}0.033^{* * *} \\
{[0.012]}\end{array}$ & $\begin{array}{c}0.038^{* * *} \\
{[0.013]}\end{array}$ & $\begin{array}{c}0.030^{* * *} \\
{[0.012]}\end{array}$ & $\begin{array}{c}0.040^{* * *} \\
{[0.013]}\end{array}$ & $\begin{array}{c}0.031^{* * *} \\
{[0.012]}\end{array}$ & $\begin{array}{c}0.039^{* * *} \\
{[0.013]}\end{array}$ & $\begin{array}{c}0.034^{* * *} \\
{[0.012]}\end{array}$ \\
\hline Tenure & $\begin{array}{l}-0.018 \\
{[0.026]}\end{array}$ & $\begin{array}{c}0.011 \\
{[0.023]}\end{array}$ & $\begin{array}{l}-0.025 \\
{[0.024]}\end{array}$ & $\begin{array}{l}-0.004 \\
{[0.022]}\end{array}$ & $\begin{array}{l}-0.027 \\
{[0.024]}\end{array}$ & $\begin{array}{l}-0.004 \\
{[0.022]}\end{array}$ & $\begin{array}{l}-0.022 \\
{[0.026]}\end{array}$ & $\begin{array}{c}0.006 \\
{[0.023]}\end{array}$ \\
\hline Chairman & $\begin{array}{l}-0.171 \\
{[0.187]}\end{array}$ & $\begin{array}{l}-0.209 \\
{[0.172]}\end{array}$ & $\begin{array}{l}-0.165 \\
{[0.184]}\end{array}$ & $\begin{array}{l}-0.264 \\
{[0.167]}\end{array}$ & $\begin{array}{l}-0.142 \\
{[0.184]}\end{array}$ & $\begin{array}{l}-0.245 \\
{[0.167]}\end{array}$ & $\begin{array}{l}-0.179 \\
{[0.188]}\end{array}$ & $\begin{array}{l}-0.227 \\
{[0.174]}\end{array}$ \\
\hline Ownpct & $\begin{array}{c}-0.020^{*} \\
{[0.010]}\end{array}$ & $\begin{array}{c}-0.029^{* * * *} \\
{[0.010]}\end{array}$ & $\begin{array}{r}-0.018^{*} \\
{[0.010]}\end{array}$ & $\begin{array}{c}-0.020^{* *} \\
{[0.010]}\end{array}$ & $\begin{array}{c}-0.020^{* *} \\
{[0.010]}\end{array}$ & $\begin{array}{c}-0.021^{* *} \\
{[0.010]}\end{array}$ & $\begin{array}{c}-0.019^{*} \\
{[0.010]}\end{array}$ & $\begin{array}{c}-0.027^{* *} \\
{[0.011]}\end{array}$ \\
\hline \multicolumn{9}{|l|}{ Firm characteristics: } \\
\hline Size & $\begin{array}{c}0.045 \\
{[0.078]}\end{array}$ & $\begin{array}{l}0.119^{*} \\
{[0.066]}\end{array}$ & $\begin{array}{c}0.012 \\
{[0.071]}\end{array}$ & $\begin{array}{c}0.08 \\
{[0.063]}\end{array}$ & $\begin{array}{c}0.068 \\
{[0.073]}\end{array}$ & $\begin{array}{l}0.121^{*} \\
{[0.064]}\end{array}$ & $\begin{array}{c}0.022 \\
{[0.081]}\end{array}$ & $\begin{array}{l}0.118^{*} \\
{[0.069]}\end{array}$ \\
\hline ROA & $\begin{array}{l}-0.149 \\
{[0.951]}\end{array}$ & $\begin{array}{c}-1.739^{* * *} \\
{[0.656]}\end{array}$ & $\begin{array}{c}0.117 \\
{[0.940]}\end{array}$ & $\begin{array}{c}-1.497^{* *} \\
{[0.642]}\end{array}$ & $\begin{array}{l}-0.182 \\
{[0.930]}\end{array}$ & $\begin{array}{c}-1.474^{* *} \\
{[0.646]}\end{array}$ & $\begin{array}{l}-0.399 \\
{[0.961]}\end{array}$ & $\begin{array}{c}-1.863^{* * *} \\
{[0.676]}\end{array}$ \\
\hline Leverage & $\begin{array}{c}-0.29 \\
{[0.262]}\end{array}$ & $\begin{array}{c}0.289 \\
{[0.178]}\end{array}$ & $\begin{array}{l}-0.317 \\
{[0.253]}\end{array}$ & $\begin{array}{l}0.329^{*} \\
{[0.177]}\end{array}$ & $\begin{array}{l}-0.203 \\
{[0.258]}\end{array}$ & $\begin{array}{c}0.378^{* *} \\
{[0.180]}\end{array}$ & $\begin{array}{l}-0.207 \\
{[0.268]}\end{array}$ & $\begin{array}{c}0.294 \\
{[0.189]}\end{array}$ \\
\hline Tangibility & $\begin{array}{l}-0.366 \\
{[0.606]}\end{array}$ & $\begin{array}{c}0.041 \\
{[0.521]}\end{array}$ & $\begin{array}{l}-0.434 \\
{[0.598]}\end{array}$ & $\begin{array}{c}0.067 \\
{[0.504]}\end{array}$ & $\begin{array}{c}-0.6 \\
{[0.611]}\end{array}$ & $\begin{array}{c}0.003 \\
{[0.511]}\end{array}$ & $\begin{array}{l}-0.515 \\
{[0.617]}\end{array}$ & $\begin{array}{c}0.005 \\
{[0.531]}\end{array}$ \\
\hline \multicolumn{9}{|l|}{ Investors: } \\
\hline Before $\times$ Large institution & $\begin{array}{l}-0.411 \\
{[0.358]}\end{array}$ & $\begin{array}{c}-0.781^{* *} \\
{[0.370]}\end{array}$ & & & & & $\begin{array}{l}-0.485 \\
{[0.366]}\end{array}$ & $\begin{array}{c}-0.672^{*} \\
{[0.376]}\end{array}$ \\
\hline During $\times$ Large institution & $\begin{array}{c}0.13 \\
{[0.261]}\end{array}$ & $\begin{array}{c}-0.569^{* *} \\
{[0.238]}\end{array}$ & & & & & $\begin{array}{c}0.043 \\
{[0.263]}\end{array}$ & $\begin{array}{c}-0.604^{* *} \\
{[0.241]}\end{array}$ \\
\hline \multicolumn{9}{|l|}{ Bank lenders: } \\
\hline Before $\times$ Large bank loan & & & $\begin{array}{l}-0.337 \\
{[0.523]}\end{array}$ & $\begin{array}{l}-0.369 \\
{[0.518]}\end{array}$ & & & $\begin{array}{l}-0.209 \\
{[0.548]}\end{array}$ & $\begin{array}{l}-0.303 \\
{[0.543]}\end{array}$ \\
\hline During $\times$ Large bank loan & & & $\begin{array}{l}-0.539 \\
{[0.435]}\end{array}$ & $\begin{array}{c}0.445 \\
{[0.282]}\end{array}$ & & & $\begin{array}{l}-0.563 \\
{[0.449]}\end{array}$ & $\begin{array}{c}0.262 \\
{[0.314]}\end{array}$ \\
\hline DIP & & & $\begin{array}{c}0.474^{* *} \\
{[0.216]}\end{array}$ & $\begin{array}{l}0.322^{*} \\
{[0.193]}\end{array}$ & & & $\begin{array}{l}0.498^{* *} \\
{[0.224]}\end{array}$ & $\begin{array}{l}0.391^{*} \\
{[0.203]}\end{array}$ \\
\hline \multicolumn{9}{|l|}{ Unsecured creditors: } \\
\hline Before $\times$ Large bond liability & & & & & $\begin{array}{l}-0.052 \\
{[0.587]}\end{array}$ & $\begin{array}{c}0.593 \\
{[0.430]}\end{array}$ & $\begin{array}{l}-0.238 \\
{[0.610]}\end{array}$ & $\begin{array}{c}0.47 \\
{[0.468]}\end{array}$ \\
\hline During $\times$ Large bond liability & & & & & $\begin{array}{l}-0.001 \\
{[0.392]}\end{array}$ & $\begin{array}{l}-0.402 \\
{[0.352]}\end{array}$ & $\begin{array}{l}-0.025 \\
{[0.406]}\end{array}$ & $\begin{array}{c}-0.28 \\
{[0.372]}\end{array}$ \\
\hline Before $\times$ Large nondebt liability & & & & & $\begin{array}{c}0.223 \\
{[0.465]}\end{array}$ & $\begin{array}{l}-1.997^{*} \\
{[1.042]}\end{array}$ & $\begin{array}{c}0.198 \\
{[0.475]}\end{array}$ & $\begin{array}{c}-1.982^{*} \\
{[1.050]}\end{array}$ \\
\hline During $\times$ Large nondebt liability & & & & & $\begin{array}{c}-0.916^{* *} \\
{[0.361]}\end{array}$ & $\begin{array}{c}-0.514^{*} \\
{[0.278]}\end{array}$ & $\begin{array}{c}-0.974^{* * *} \\
{[0.368]}\end{array}$ & $\begin{array}{c}-0.548^{*} \\
{[0.293]}\end{array}$ \\
\hline Prepack & $\begin{array}{l}-0.127 \\
{[0.383]}\end{array}$ & $\begin{array}{l}-0.321 \\
{[0.335]}\end{array}$ & $\begin{array}{l}42^{-0.16} \\
{[0.380]}\end{array}$ & $\begin{array}{c}-0.31 \\
{[0.331]}\end{array}$ & $\begin{array}{l}-0.303 \\
{[0.380]}\end{array}$ & $\begin{array}{l}-0.312 \\
{[0.336]}\end{array}$ & $\begin{array}{l}-0.218 \\
{[0.388]}\end{array}$ & $\begin{array}{c}-0.4 \\
{[0.346]}\end{array}$ \\
\hline $\mathrm{N}$ & 1,5 & 87 & 1,6 & & 1,6 & 38 & $1,5 \xi$ & \\
\hline of which $\mathrm{N}$ (internal) and $\mathrm{N}$ (external) & 143 & 194 & 146 & 198 & 146 & 198 & 143 & 193 \\
\hline Pseudo $R^{2}$ & 0.1 & 13 & 0.1 & & 0.1 & 12 & 0.1 & 26 \\
\hline
\end{tabular}




\section{Table 8 \\ Separation pay to departing CEOs}

The table shows the severance payment in $\$$ thousands by year of CEO departure relative to bankruptcy filing (Panel A), reason for departure (Panel B), and type of new employment (Panel C), respectively. The mean and median severance pay is conditional on receiving severance. The last column shows the median severance payment in percent of the CEO's salary before turnover. The sample is 474 CEOs who left their position between year-end -2 (where 0 is the year of filing) and three years after emergence at 342 large US firms filing for Chapter 11 in 1996-2007. All variables are defined in Appendix 1.

\begin{tabular}{|c|c|c|c|c|c|c|c|c|c|c|}
\hline \multirow[b]{3}{*}{ All } & \multirow[b]{2}{*}{$N$} & \multirow{2}{*}{$\begin{array}{l}\% \text { CEOs } \\
\text { receiving } \\
\text { severance }\end{array}$} & \multicolumn{2}{|c|}{$\begin{array}{c}\text { Contractual } \\
\text { severance }\end{array}$} & \multicolumn{2}{|c|}{$\begin{array}{c}\text { Discretional } \\
\text { severance } \\
\end{array}$} & \multicolumn{4}{|c|}{ Total severance } \\
\hline & & & mean & median & mean & median & mean & $\%$ & median & $\%$ \\
\hline & 474 & 28 & 1,698 & 517 & 1,833 & 376 & 3,531 & 582 & 1,579 & 306 \\
\hline \multicolumn{11}{|c|}{ A: Severance paid by relative year of departure } \\
\hline-2 & 60 & 25 & 1,199 & 311 & 1,449 & 698 & 2,649 & 471 & 2,146 & 417 \\
\hline-1 & 83 & 39 & 1,124 & 249 & 739 & 322 & 1,863 & 316 & 901 & 214 \\
\hline 0 & 100 & 32 & 1,126 & 911 & 3,407 & 336 & 4,533 & 819 & 1,602 & 269 \\
\hline 1 & 113 & 26 & 2,523 & 296 & 1,547 & 495 & 4,070 & 551 & 1,383 & 387 \\
\hline 2 & 75 & 24 & 3,170 & 1,142 & 2,148 & 8 & 5,317 & 834 & 3,002 & 348 \\
\hline 3 & 30 & 10 & 1,231 & 1,011 & 461 & 31 & 1,691 & 578 & 1,772 & 578 \\
\hline $4+$ & 13 & 15 & 872 & 872 & 2 & 2 & 875 & 113 & 875 & 113 \\
\hline \multicolumn{11}{|c|}{ B: Severance paid by reason for turnover } \\
\hline Resigned for personal reasons & 99 & 41 & 1,794 & 562 & 1,182 & 407 & 2,976 & 538 & 1,672 & 313 \\
\hline Pursue other interest & 56 & 38 & 1,486 & 653 & 353 & 0 & 1,839 & 361 & 924 & 191 \\
\hline $\begin{array}{l}\text { Pressured by the board, } \\
\text { shareholders, or creditors }\end{array}$ & 63 & 40 & 3,370 & 1,091 & 4,293 & 1,495 & 7,663 & 836 & 3,333 & 429 \\
\hline Liquidation or acquisition & 91 & 1 & 0 & 0 & 314 & 314 & 314 & & 314 & \\
\hline Retirement or normal succession & 70 & 10 & 877 & 0 & 2,041 & 1,181 & 2,918 & 467 & 3,845 & 575 \\
\hline Death or illness & 2 & 0 & 0 & 0 & 0 & 0 & 0 & 0 & 0 & 0 \\
\hline Other reasons & 27 & 30 & 555 & 489 & 1,963 & 1,169 & 2,518 & 310 & 1,431 & 202 \\
\hline No reason given & 49 & 39 & 728 & 494 & 607 & 212 & 1,334 & 709 & 901 & 224 \\
\hline Forced & 241 & 32 & 1,919 & 611 & 2,206 & 391 & 4,125 & 654 & 1,772 & 339 \\
\hline Voluntary & 233 & 24 & 1,380 & 400 & 1,294 & 313 & 2,674 & 474 & 1,469 & 244 \\
\hline \multicolumn{11}{|c|}{ C: Severance paid by type of new employment of the departed CEO } \\
\hline Stay as chairman & 33 & 0 & 0 & 0 & 0 & 0 & 0 & 0 & 0 & 0 \\
\hline Retaining honorary position & 46 & 46 & 425 & 0 & 1,868 & 524 & 2,292 & 317 & 1,271 & 238 \\
\hline CEO at a public company & 28 & 39 & 1,912 & 1,701 & 2,377 & 914 & 4,289 & 665 & 2,561 & 387 \\
\hline $\mathrm{CEO}$ at a private company & 70 & 40 & 2,810 & 880 & 922 & 128 & 3,733 & 803 & 1,328 & 200 \\
\hline Non-CEO executive at a public company & 52 & 25 & 1,609 & 395 & 1,755 & 429 & 3,364 & 514 & 2,363 & 599 \\
\hline Non-CEO executive at a private company & 44 & 34 & 1,828 & 611 & 1,041 & 2 & 2,869 & 526 & 899 & 268 \\
\hline Consultant or politician & 19 & 26 & 58 & 0 & 921 & 422 & 979 & 215 & 422 & 200 \\
\hline Self-employed & 26 & 35 & 1,797 & 735 & 8,653 & 1,181 & 10,450 & 1,373 & 2,824 & 600 \\
\hline No new employment & 156 & 19 & 1,779 & 909 & 893 & 32 & 2,672 & 453 & 1,740 & 313 \\
\hline
\end{tabular}




\section{Table 9 \\ Methodology for estimating CEO income at new employment}

The table describes the methodology used to estimate the CEO's income at new employment. For the CEO's income from the old position, we use the first available observation on pay between -3 and plan confirmation. That is, if a CEO is hired in year -2 and left the company in year 0 , we use her pay in year -2 as the benchmark.

Type of new employment

Keep the CEO job

Stay as Chairman

Retaining honorary position

CEO at a public company

CEO at a private company

Non-CEO executive at a public company

Non-CEO executive at a private firm

Consultant or politician

Self-employed

No new employment (retirement, death, back to school, jail, under investigation etc.)
Methodology for estimating CEO income

This category includes CEOs that are hired either before year -3 or during our sample period and do not depart as of the last year of our observations. The pay at old position for these CEOs is measured in year -3 or the year of their hiring. The pay at the new position is measured as of the last fiscal year that contains compensation information. We drop cases where the last available fiscal year on compensation is the year of their hiring.

We find the non-CEO chairman in the Execcomp database, if possible. If not, We use the non-CEO Chairman pay of the median firm in sales in the same 2-digit SIC industry.

Zero income.

We find the CEO in the Execcomp database, if possible. If not, we use the 2-digit SIC and closest in sales, assets or employee (whichever is available) of the new company to find a match in Execcomp and use its CEO's pay as a proxy.

We use the 2-digit SIC and closest in sales, assets or employee (whichever is available) of the new company to find a match in Execcomp and use its CEO's pay as a proxy. If none of the size variables is available, we use the industry median in sales. The matched CEO pay at the public firm is adjusted for private firms following Gao, Lemmon, and Li (2011). That is, we adjust the public company pay with a $12 \%$ cut in cash pay and $30 \%$ cut in grants and total pay.

We take an average of the top non-CEO executive pay at the public company where the CEO works at (from the Execcomp database). If the public company is not in Execcomp we use the 2-digit SIC and closest in sales, assets or employee (whichever available) of the new company to find a matching firm in Execcomp and use the average of its top non-CEO executive pay as a proxy.

We use the 2-digit SIC and closest in sales, assets or employee (whichever available) of the new company to find a matching firm in Execcomp and use the average of its top non-CEO executive pay as a proxy. If none of the size variables is available, we use the industry median in sales. The matched non-CEO executive pay at the public firm is adjusted for private firms following Gao, Lemmon, and $\mathrm{Li}$ (2011). For two junior managers in the sample, we take $50 \%$ of the level of pay to senior executives at an industry and size matched firm.

We assume and annual pay of $\$ 300,000$ in 1995 dollars. This is the average salary offered to principals at Mckinsey over the sample period. This is also close to the median annual consulting contract offered to some of the departed CEOs.

We use the one-digit SIC and the median pay of a company in the bottom decile in number of employees as a match.

Zero income. 


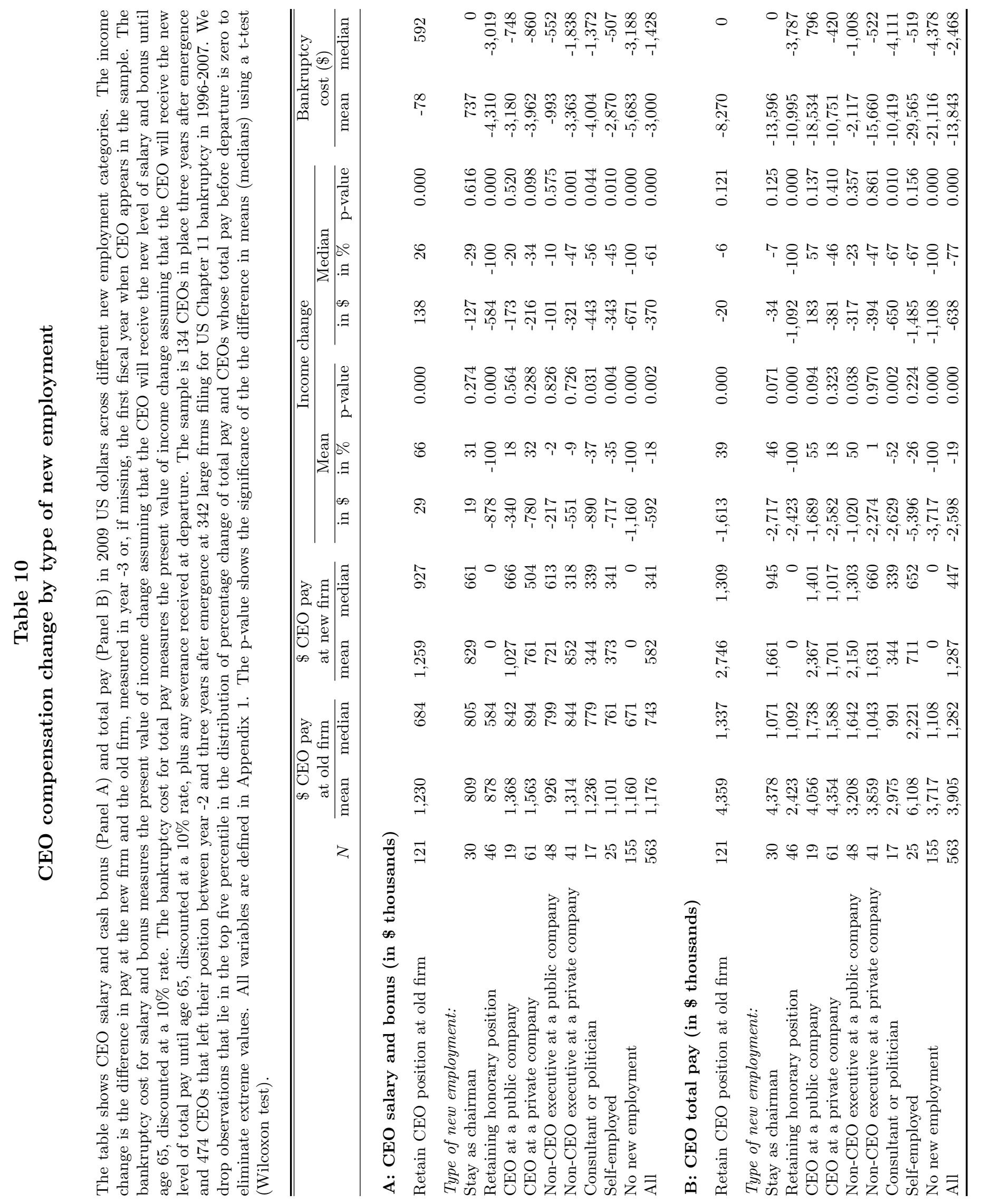




\section{Table 11 \\ CEO total compensation change across various subsamples}

The table shows estimates of the change in CEO total compensation (TotalPay) in $\$$ thousands and percent, divided by reason of turnover (Panel A), type of new employment (Panel B), relative year of departure (Panel C), age (Panel $\mathrm{D})$, tenure (Panel E), and timing of CEO hiring and departure (Panel F) respectively. Compensation change is the difference in pay at the new firm and the old firm measured in the first fiscal year when the CEO enters into our sample. Bankruptcy cost measures the present value (PV) of income change assuming that the CEO receives the new level of pay until age 65 , discounted at a $10 \%$ rate, plus any severance pay received at departure. The sample is 134 CEOs in place up to three years after emergence and 474 CEOs that left their position between year -2 and three years after emergence at 342 large firms filing for US Chapter 11 bankruptcy in 1996-2007. We drop observations that lie in the top five percentile in the distribution of percentage change of total pay and CEOs whose total pay before departure is zero to eliminate extreme values. All variables are defined in Appendix 1.

\begin{tabular}{|c|c|c|c|c|c|c|c|}
\hline & \multirow[b]{3}{*}{$N$} & \multicolumn{4}{|c|}{ Change in total compensation } & \multirow{2}{*}{\multicolumn{2}{|c|}{$\begin{array}{c}\text { Bankruptcy } \\
\text { cost }\end{array}$}} \\
\hline & & \multicolumn{2}{|c|}{ mean } & \multicolumn{2}{|c|}{ median } & & \\
\hline & & in $\$$ & in $\%$ & in $\$$ & in $\%$ & mean & median \\
\hline All & 541 & $-2,598$ & -19 & -638 & -77 & $-14,659$ & $-2,695$ \\
\hline \multicolumn{8}{|l|}{ A: Income change by reason for departure } \\
\hline Voluntary & 195 & $-1,915$ & -23 & -654 & -85 & $-6,903$ & $-1,264$ \\
\hline Forced & 225 & $-3,710$ & -47 & -930 & -100 & $-22,896$ & $-4,317$ \\
\hline No turnover & 121 & $-1,613$ & 39 & -20 & -6 & $-8,270$ & 0 \\
\hline \multicolumn{8}{|l|}{ B: Income change by type of subsequent employment } \\
\hline Retain CEO position or chairmanship & 151 & $-1,832$ & 41 & -28 & -6 & $-9,335$ & 0 \\
\hline Full-time employee at a new company & 169 & $-1,973$ & 27 & -292 & -33 & $-10,429$ & -436 \\
\hline Consultant/self-employed/honorary position & 88 & $-3,198$ & -72 & $-1,035$ & -100 & $-15,415$ & $-3,112$ \\
\hline No new employment & 155 & $-3,717$ & -100 & $-1,108$ & -100 & $-21,116$ & $-4,378$ \\
\hline \multicolumn{8}{|c|}{ C: Income change by CEO departure year relative to Chapter 11 filing } \\
\hline Year -2 to -1 & 161 & $-1,947$ & -22 & -598 & -75 & $-10,291$ & $-2,118$ \\
\hline Year 0 to 1 & 202 & $-3,639$ & -28 & -730 & -95 & $-20,056$ & $-2,953$ \\
\hline Year 2 and after & 178 & $-1,994$ & -6 & -549 & -59 & $-10,031$ & $-1,925$ \\
\hline \multicolumn{8}{|l|}{ D: Income change by CEO age at departure } \\
\hline Less than 50 years old & 150 & $-2,766$ & 11 & -579 & -67 & $-22,739$ & $-4,380$ \\
\hline $51-60$ years old & 264 & $-2,526$ & -24 & -630 & -75 & $-12,775$ & $-2,980$ \\
\hline More than 60 years old & 116 & $-2,727$ & -47 & -809 & -98 & $-4,821$ & 0 \\
\hline \multicolumn{8}{|l|}{ E: Income change by CEO tenure at departure } \\
\hline Less than 3 year & 190 & $-1,948$ & -10 & -518 & -73 & $-11,008$ & $-2,489$ \\
\hline 4-6 year & 170 & $-2,605$ & -11 & -628 & -72 & $-14,323$ & $-2,587$ \\
\hline More than 6 years & 175 & $-3,367$ & -36 & -828 & -90 & $-16,615$ & $-2,461$ \\
\hline \multicolumn{8}{|c|}{ F: Income change by timing of CEO hiring the departure } \\
\hline Incumbent CEOs that stay till 3 years after emergence & 41 & $-2,164$ & 10 & -133 & -14 & $-11,271$ & -646 \\
\hline New CEOs that stay till 3 years after emergence & 80 & $-1,330$ & 55 & 57 & 7 & $-6,770$ & 218 \\
\hline CEOs that leave before Chapter 11 filing & 133 & $-2,259$ & -28 & -672 & -92 & $-11,641$ & $-2,561$ \\
\hline Incumbent CEOs leaving after filing (before resolution) & 97 & $-4,586$ & -52 & $-1,245$ & -100 & $-26,676$ & $-3,967$ \\
\hline New CEOs leaving after filing but (before resolution) & 110 & $-3,140$ & -36 & -741 & -96 & $-16,582$ & $-3,596$ \\
\hline Incumbent CEOs that leave after emergence & 31 & $-2,200$ & -38 & -930 & -93 & $-8,961$ & $-1,703$ \\
\hline New CEOs that leave after emergence & 49 & $-1,010$ & -21 & -520 & -84 & $-4,596$ & $-1,649$ \\
\hline
\end{tabular}


Table 12

\section{CEO total compensation change of incumbent and new CEOs}

The table shows estimates of the change in CEO total compensation (TotalPay) in $\$$ thousands and percent, divided by whether the CEO in place is the incumbent CEO at the beginning of our sample or newly hired CEOs during our sample (Panel A), and whether the turnover is forced or voluntary (Panel B), respectively. Income change is the difference in total pay at the new firm and the old firm measured in the first fiscal year for the CEO enters into our sample. Bankruptcy cost is the present value (PV) of income change assuming that the CEO receives the new level of pay until age 65 , discounted at a $10 \%$ rate, plus any severance payment at departure. The sample is $134 \mathrm{CEOs} \mathrm{in}$ place up to three years after emergence and 474 CEOs that left their position between year -2 and three years after emergence at 342 large firms filing for US Chapter 11 bankruptcy in 1996-2007. We drop observations that lie in the top five percentile in the distribution of percentage change of total pay and CEOs whose total pay before departure is zero to eliminate extreme values. All variables are defined in Appendix 1.

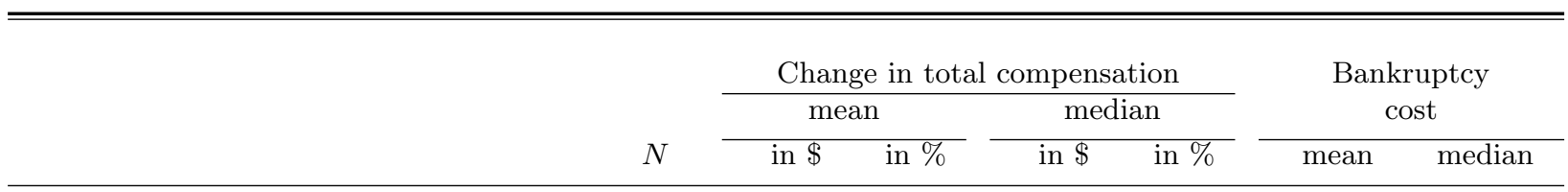

\section{A: Incumbent CEOs vs. newly hired CEOs}

\section{All Incumbent CEOs}

Retain CEO position at old firm

Stay as chairman

CEO at a public company

CEO at a private company

Non-CEO executive at a public company

Non-CEO executive at a private company

All full-time employment categories

Other employment or no employment

\section{All newly hired CEOs}

Retain CEO position at old firm

Stay as chairman

CEO at a public company

CEO at a private company

Non-CEO executive at a public company

Non-CEO executive at a private company

All full-time employment categories

Other employment or no employment

$\begin{array}{cr}41 & -2,164 \\ 19 & -823 \\ 8 & -2,445 \\ 31 & -2,667 \\ 19 & -949 \\ 20 & -645 \\ 138 & -1,721 \\ 133 & -4,337\end{array}$

10
56
11
28
64
-31
22
-89

-133
-28
-880
-131
-136
-394
-141

$-14 \quad-11,271$

$-3 \quad-8,595$

$-32 \quad-24,216$

$-9 \quad-11,067$

$-12 \quad-3,353$

$-49 \quad-2,062$

$-16 \quad-9,190$

$\begin{array}{lll}-1,352 & -100 \quad-22,334\end{array}$

$$
\begin{array}{r}
-646 \\
0 \\
-8,063 \\
-100 \\
-131 \\
-479 \\
-174 \\
-3,787
\end{array}
$$

$\begin{array}{cc}80 & -1,330 \\ 11 & -5,988 \\ 11 & -1,139 \\ 27 & -2,485 \\ 25 & -1,075 \\ 20 & -3,904 \\ 174 & -2,051 \\ 96 & -2,420\end{array}$

55
28
87
5
40
32
43
-92

57
-322
585
-462
-615
-127
-68
-827$$
\begin{array}{r}
7 \\
-41 \\
66
\end{array}
$$$$
-6,770
$$$$
-22,232
$$$$
-14,556
$$$$
-10,371
$$$$
-1,189
$$$$
-28,544
$$

218

$$
0
$$$$
2,321
$$$$
-594
$$$$
-1,433
$$

$$
\begin{array}{rr}
-9 & -10,425 \\
-100 & -15,125
\end{array}
$$

\section{B: Forced departure vs. voluntary departure}

\section{All forced}

Stay as chairman

CEO at a public company

CEO at a private company

Non-CEO executive at a public company

Non-CEO executive at a private company

All full-time employment categories

Other employment or no employment

$\begin{array}{cc}3 & -1,144 \\ 13 & -3,096 \\ 38 & -3,212 \\ 17 & -1,981 \\ 14 & -1,784 \\ 85 & -2,640\end{array}$

73
50
11
-10
44
20
-88

995
-173
-691
-620
71
-462
$-1,196$

$\begin{array}{rrr}133 & -8,429 & 7,786 \\ -20 & -29,060 & -3,633 \\ -57 & -15,424 & -3,107 \\ -62 & -12,954 & -2,469 \\ 31 & -9,558 & 2,171 \\ -47 & -15,717 & -1,433 \\ -100 & -27,057 & -5,255\end{array}$

\section{All voluntary}

Stay as chairman

CEO at a public company

$\mathrm{CEO}$ at a private company

Non-CEO executive at a public company

Non-CEO executive at a private company All full-time employment categories Other employment or no employment

\begin{tabular}{crrrrrr}
27 & $-2,891$ & 43 & -40 & -11 & $-14,170$ & 0 \\
6 & 1,359 & 66 & 444 & 67 & 6,729 & 2,430 \\
20 & $-1,386$ & 31 & -131 & -12 & $-1,899$ & 0 \\
27 & -415 & 89 & 428 & 32 & 3,904 & 0 \\
26 & $-2,538$ & -23 & -569 & -63 & $-19,376$ & $-4,331$ \\
106 & $-1,649$ & 37 & -169 & -18 & $-7,181$ & 0 \\
89 & $-2,232$ & -94 & -814 & -100 & $-6,903$ & $-1,264$ \\
\hline
\end{tabular}




\section{Table 13}

\section{Regressions for CEO compensation}

The table shows the coefficient estimates from ordinary least squares (OLS) regressions for the logarithm of total CEO compensation in columns (1) to (3) and coefficients estimates from Tobit regressions for the proportion cash of the total CEO compensation in columns (4) to(6). The sample is 1,524 firm-years from year -3 to 3 years after emergence or liquidation for 342 large firms filing for US Chapter 11 bankruptcy in 1996-2007. All regressions control for industry fixed effects at the 2-digit SIC code level. Standard errors are in brackets. ${ }^{* * *}$, $^{* *}$, and ${ }^{*}$ denotes significance at the $1 \%, 5 \%$ and $10 \%$ level, respectively. All variables are defined in Appendix 1.

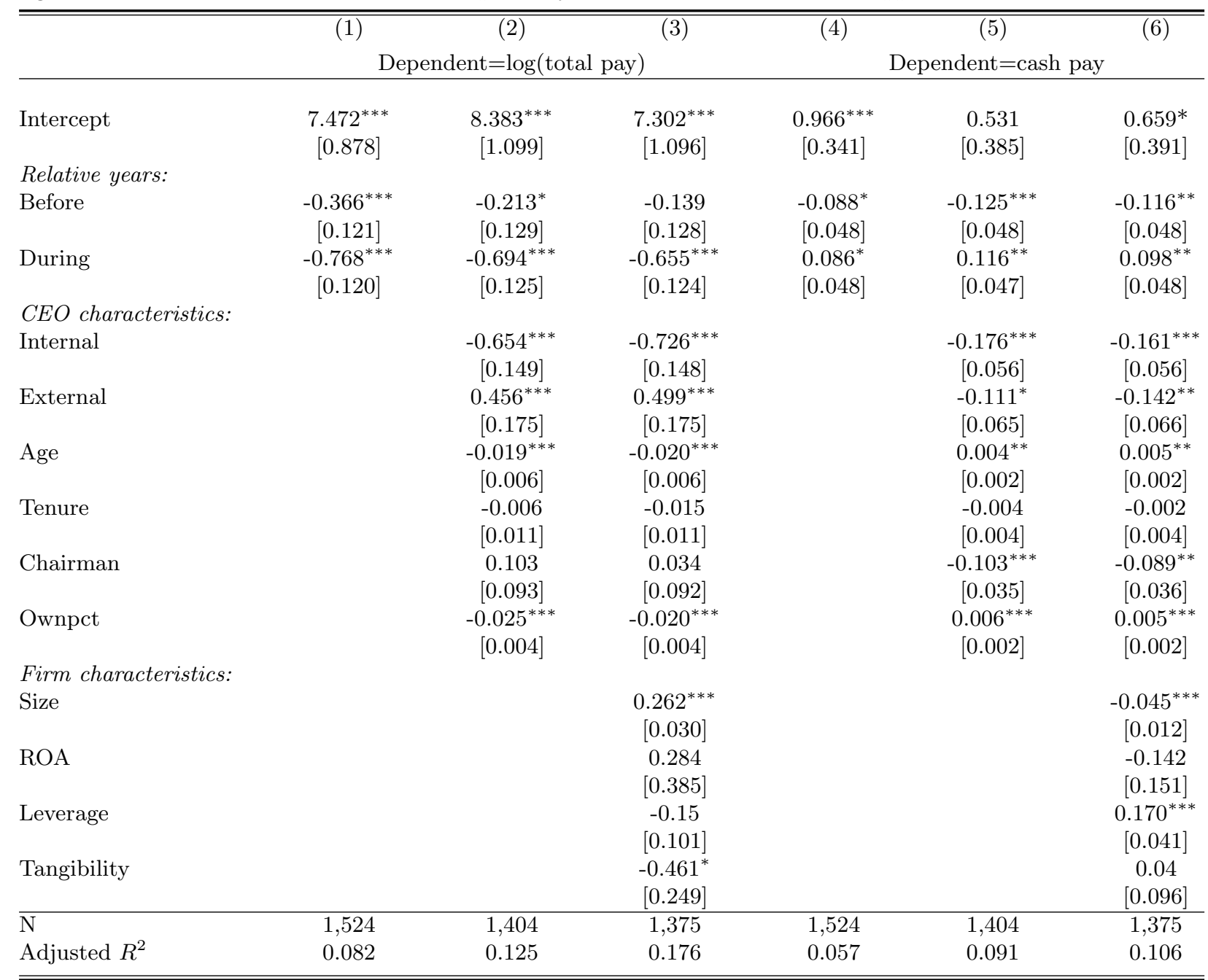




\section{Table 14}

\section{Regressions for the probability that the departed CEO gets rehired and the PV of the change in CEO total compensation}

The table shows the coefficient estimates from a logit regressions for the probability that the departed CEO gets rehired and from an ordinary least squares (OLS) regression of the CEO bankruptcy cost. In regression (1), the dependent variable takes the value of one if the departed CEO stays as chairman, or becomes a CEO or a non-CEO executive or director at another firm upon departure. In regression (2), the dependent variable is the PV of the change in total compensation from the old to the new position, through the age of 65 and discounted at a $10 \%$ rate, plus any severance payment received. The sample is 442 CEOs leaving her position between year -2 and liquidation or 3 years after emergence for 342 large firms filing for US Chapter 11 bankruptcy in 1996-2007. Standard errors are in brackets. ${ }^{* * *},{ }^{* *}$, and ${ }^{*}$ denotes significance at the $1 \%, 5 \%$ and $10 \%$ level, respectively. All variables are defined in Appendix 1.

\begin{tabular}{lcc}
\hline \hline & $(1)$ & $(2)$ \\
& CEO gets rehired & PV of compensation change \\
\hline Intercept & $3.305^{* * *}$ & $-57.341^{* * *}$ \\
& {$[0.759]$} & {$[16.120]$} \\
Relative years: & & 0.722 \\
Before & -0.241 & {$[7.894]$} \\
& {$[0.352]$} & -3.893 \\
During & $-0.575^{* *}$ & {$[5.359]$} \\
CEO characteristics: & {$[0.240]$} & $1.090^{* * *}$ \\
Age & & {$[0.283]$} \\
Tenure & $-0.049^{* * *}$ & $-1.172^{* *}$ \\
Chairman & {$[0.013]$} & {$[0.520]$} \\
Bankruptcy outcome: & $-0.046^{*}$ & $-8.735^{*}$ \\
Liquidation & {$[0.024]$} & {$[4.693]$} \\
& 0.194 & -5.661 \\
Pseudo $R^{2} /$ Adjusted $R^{2}$ & {$[0.210]$} & {$[5.856]$} \\
\hline \hline
\end{tabular}


Table 15

Expected CEO bankruptcy costs and probability of forced and voluntary turnover

The table shows the coefficient estimates from multinomial logit regressions for the probability of CEO turnover. All models have three outcomes: no turnover $(\mathrm{N}=1,244)$, voluntary turnover $(\mathrm{N}=156)$, and forced turnover ( $=148)$. The sample is 1,548 firm-years from year -2 to liquidation or 3 years after emergence for 342 large firms filing for US Chapter 11 bankruptcy in 1996-2007. The CEO bankruptcy costs are the predicted values, respectively, from the two regression in Table 14. All regressions control for industry fixed effects at the 2-digit SIC code level. Standard errors are in brackets. ${ }^{* *},{ }^{* *}$, and ${ }^{*}$ denotes significance at the $1 \%, 5 \%$ and $10 \%$ level, respectively. All variables are defined in Appendix 1.

\begin{tabular}{|c|c|c|c|c|}
\hline & & & & \\
\hline & Voluntary & Forced & Voluntary & Forced \\
\hline Intercept & $\begin{array}{c}-23.697^{* * *} \\
{[1.482]}\end{array}$ & $\begin{array}{l}-2.232 \\
{[1.803]}\end{array}$ & $\begin{array}{c}-26.666^{* * *} \\
{[1.373]}\end{array}$ & $\begin{array}{l}-2.564 \\
{[1.645]}\end{array}$ \\
\hline CEO bankruptcy costs: & & & & \\
\hline Expected probability of being rehired & $\begin{array}{c}-4.506^{* * *} \\
{[0.916]}\end{array}$ & $\begin{array}{l}-0.319 \\
{[0.979]}\end{array}$ & & \\
\hline Expected PV of total compensation change & & & $\begin{array}{c}0.053^{* * *} \\
{[0.011]}\end{array}$ & $\begin{array}{l}-0.008 \\
{[0.011]}\end{array}$ \\
\hline Relative years: & & & & \\
\hline Before & $\begin{array}{l}-0.021 \\
{[0.383]}\end{array}$ & $\begin{array}{c}0.150 .398 \\
{\left[\begin{array}{ll}0.518\end{array}\right]}\end{array}$ & $\begin{array}{c}0.133 \\
{[0.378]}\end{array}$ & {$[0.518]$} \\
\hline During & $\begin{array}{l}-0.014 \\
{[0.330]}\end{array}$ & $\begin{array}{c}1.958^{* * *} \\
{[0.364]}\end{array}$ & $\begin{array}{c}0.956^{* * *} \\
{[0.309]}\end{array}$ & $\begin{array}{c}1.953^{* * *} \\
{[0.343]}\end{array}$ \\
\hline CEO characteristics: & & & & \\
\hline Ownpct & $\begin{array}{c}-0.045^{* * *} \\
{[0.014]}\end{array}$ & $\begin{array}{l}-0.004 \\
{[0.009]}\end{array}$ & $\begin{array}{c}-0.024^{* *} \\
{[0.012]}\end{array}$ & $\begin{array}{l}-0.004 \\
{[0.009]}\end{array}$ \\
\hline Firm characteristics: & & & & \\
\hline Size & $\begin{array}{c}0.109 \\
{[0.080]}\end{array}$ & $\begin{array}{c}0.011 \\
{[0.078]}\end{array}$ & $\begin{array}{l}0.159^{*} \\
{[0.081]}\end{array}$ & $\begin{array}{c}0.008 \\
{[0.078]}\end{array}$ \\
\hline $\mathrm{ROA}$ & $\begin{array}{l}-0.766 \\
{[0.861]}\end{array}$ & $\begin{array}{l}-1.366^{*} \\
{[0.790]}\end{array}$ & $\begin{array}{l}-1.067 \\
{[0.865]}\end{array}$ & $\begin{array}{c}-1.373^{*} \\
{[0.789]}\end{array}$ \\
\hline Leverage & $\begin{array}{c}0.078 \\
{[0.227]}\end{array}$ & $\begin{array}{c}0.25 \\
{[0.206]}\end{array}$ & $\begin{array}{l}-0.037 \\
{[0.232]}\end{array}$ & $\begin{array}{c}0.252 \\
{[0.205]}\end{array}$ \\
\hline Tangibility & $\begin{array}{c}0.076 \\
{[0.577]}\end{array}$ & $\begin{array}{l}-0.161 \\
{[0.595]}\end{array}$ & $\begin{array}{c}0.224 \\
{[0.581]}\end{array}$ & $\begin{array}{l}-0.114 \\
{[0.596]}\end{array}$ \\
\hline Investors: & & & & \\
\hline Before $\times$ Large institution & $\begin{array}{l}-0.046 \\
{[0.377]}\end{array}$ & $\begin{array}{l}-0.784 \\
{[0.588]}\end{array}$ & $\begin{array}{c}0.008 \\
{[0.373]}\end{array}$ & $\begin{array}{l}-0.795 \\
{[0.589]}\end{array}$ \\
\hline During $\times$ Large institution & $\begin{array}{c}0.018 \\
{[0.257]}\end{array}$ & $\begin{array}{c}-0.530^{* *} \\
{[0.248]}\end{array}$ & $\begin{array}{c}0.099 \\
{[0.257]}\end{array}$ & $\begin{array}{c}-0.544^{* *} \\
{[0.250]}\end{array}$ \\
\hline Bank lenders: & & & & \\
\hline Before $\times$ Large bank loan & $\begin{array}{l}-0.801 \\
{[0.782]}\end{array}$ & $\begin{array}{c}0.281 \\
{[0.659]}\end{array}$ & $\begin{array}{l}-0.912 \\
{[0.779]}\end{array}$ & $\begin{array}{c}0.303 \\
{[0.659]}\end{array}$ \\
\hline During $\times$ Large bank loan & $\begin{array}{c}0.441 \\
{[0.366]}\end{array}$ & $\begin{array}{l}-0.494 \\
{[0.348]}\end{array}$ & $\begin{array}{c}0.471 \\
{[0.372]}\end{array}$ & $\begin{array}{l}-0.492 \\
{[0.348]}\end{array}$ \\
\hline DIP & $\begin{array}{c}0.334 \\
{[0.214]}\end{array}$ & $\begin{array}{c}0.710^{* * *} \\
{[0.233]}\end{array}$ & $\begin{array}{c}0.342 \\
{[0.213]}\end{array}$ & $\begin{array}{c}0.709^{* * *} \\
{[0.232]}\end{array}$ \\
\hline Unsecured creditors: & & & & \\
\hline Before $\times$ Large bond liability & $\begin{array}{l}0.875^{*} \\
{[0.499]}\end{array}$ & $\begin{array}{l}-0.001 \\
{[0.260}\end{array}$ & $\begin{array}{c}0.681 \\
{[0.496]}\end{array}$ & $\begin{array}{l}-0.001 \\
{[2.574]}\end{array}$ \\
\hline During $\times$ Large bond liability & $\begin{array}{c}0.106 \\
{[0.418]}\end{array}$ & $\begin{array}{l}-0.293 \\
{[0.362]}\end{array}$ & $\begin{array}{c}0.119 \\
{[0.418]}\end{array}$ & $\begin{array}{l}-0.341 \\
{[0.364]}\end{array}$ \\
\hline Before $\times$ Large nondebt liability & $\begin{array}{l}-0.528 \\
{[0.600]}\end{array}$ & $\begin{array}{l}-0.031 \\
{[0.827]}\end{array}$ & $\begin{array}{l}-0.703 \\
{[0.602]}\end{array}$ & $\begin{array}{l}-0.014 \\
{[0.829]}\end{array}$ \\
\hline During $\times$ Large nondebt liability & $\begin{array}{l}-0.291 \\
{[0.330]}\end{array}$ & $\begin{array}{c}-0.808^{* * *} \\
{[0.311]}\end{array}$ & $\begin{array}{l}-0.332 \\
{[0.330]}\end{array}$ & $\begin{array}{c}-0.808^{* * *} \\
{[0.311]}\end{array}$ \\
\hline Prepack & $\begin{array}{l}-0.0028 \\
{[0.370]}\end{array}$ & $\begin{array}{c}-0.4 \\
{[0.351]}\end{array}$ & $\begin{array}{l}-0.155 \\
{[0.372]}\end{array}$ & $\begin{array}{r}-0.380 \\
{[0.353]}\end{array}$ \\
\hline
\end{tabular}


Table 16

\section{Expected CEO bankruptcy cost and CEO compensation}

The table shows coefficient estimates from ordinary least squares (OLS) regressions for the total CEO compensation (models 1 and 2) and the proportion cash pay (models 3 and 4). The dependent variables are $\log ($ TotalPay) and CashPay, respectively. The sample is 1,325 firm-years from year -3 to liquidation or 3 years after emergence for 342 large firms filing for US Chapter 11 bankruptcy in 1996-2007. The CEO bankruptcy costs are the predicted values, respectively, from the two regression in Table 14. All regressions control for industry fixed effects at the 2-digit SIC code level. Standard errors are in brackets. ${ }^{* * *},{ }^{* *}$, and ${ }^{*}$ denotes significance at the $1 \%, 5 \%$ and $10 \%$ level, respectively. All variables are defined in Appendix 1.

\begin{tabular}{|c|c|c|c|c|}
\hline & \multicolumn{2}{|c|}{ Total CEO compensation } & \multicolumn{2}{|c|}{ Proportion cash pay } \\
\hline & (1) & $(2)$ & $(3)$ & $(4)$ \\
\hline Intercept & $\begin{array}{c}5.227^{* * *} \\
{[1.124]}\end{array}$ & $\begin{array}{c}6.357^{* * *} \\
{[1.077]}\end{array}$ & $\begin{array}{c}1.155^{* * *} \\
{[0.403]}\end{array}$ & $\begin{array}{c}0.928^{* *} \\
{[0.382]}\end{array}$ \\
\hline \multicolumn{5}{|l|}{ CEO bankruptcy costs: } \\
\hline Expected probability of being rehired & $\begin{array}{c}1.572^{* * *} \\
{[0.428]}\end{array}$ & & $\begin{array}{c}-0.365^{* *} \\
{[0.165]}\end{array}$ & \\
\hline Expected PV of total compensation change & & $\begin{array}{c}-0.009^{*} \\
{[0.005]}\end{array}$ & & $\begin{array}{c}0.004^{* *} \\
{[0.002]}\end{array}$ \\
\hline \multicolumn{5}{|l|}{ Relative years: } \\
\hline Before & $\begin{array}{l}-0.053 \\
{[0.129]}\end{array}$ & $\begin{array}{l}-0.156 \\
{[0.128]}\end{array}$ & $\begin{array}{c}-0.149^{* * *} \\
{[0.049]}\end{array}$ & $\begin{array}{c}-0.120^{* *} \\
{[0.048]}\end{array}$ \\
\hline During & $\begin{array}{c}-0.441^{* * *} \\
{[0.138]}\end{array}$ & $\begin{array}{c}-0.717^{* * *} \\
{[0.127]}\end{array}$ & $\begin{array}{c}0.036 \\
{[0.053]}\end{array}$ & $\begin{array}{c}0.115^{* *} \\
{[0.049]}\end{array}$ \\
\hline \multicolumn{5}{|l|}{ CEO characteristics: } \\
\hline Internal & $\begin{array}{c}-0.714^{* * *} \\
{[0.143]}\end{array}$ & $\begin{array}{c}-0.588^{* * *} \\
{[0.143]}\end{array}$ & $\begin{array}{c}-0.122^{* *} \\
{[0.054]}\end{array}$ & $\begin{array}{c}-0.162^{* * *} \\
{[0.054]}\end{array}$ \\
\hline External & $\begin{array}{c}0.483^{* * *} \\
{[0.174]}\end{array}$ & $\begin{array}{c}0.470^{* * *} \\
{[0.175]}\end{array}$ & $\begin{array}{c}-0.143^{* *} \\
{[0.066]}\end{array}$ & $\begin{array}{c}-0.143^{* *} \\
{[0.066]}\end{array}$ \\
\hline Ownpct & $\begin{array}{c}-0.020^{* * *} \\
{[0.004]}\end{array}$ & $\begin{array}{c}-0.025^{* * *} \\
{[0.004]}\end{array}$ & $\begin{array}{c}0.003^{* *} \\
{[0.002]}\end{array}$ & $\begin{array}{c}0.005^{* *} \\
{[0.002]}\end{array}$ \\
\hline \multicolumn{5}{|l|}{ Firm characteristics: } \\
\hline Size & $\begin{array}{c}0.260^{* * *} \\
{[0.030]}\end{array}$ & $\begin{array}{c}0.249^{* * *} \\
{[0.030]}\end{array}$ & $\begin{array}{c}-0.048^{* * *} \\
{[0.012]}\end{array}$ & $\begin{array}{c}-0.045^{* * *} \\
{[0.012]}\end{array}$ \\
\hline $\mathrm{ROA}$ & $\begin{array}{c}0.285 \\
{[0.385]}\end{array}$ & $\begin{array}{c}0.235 \\
{[0.386]}\end{array}$ & $\begin{array}{l}-0.154 \\
{[0.151]}\end{array}$ & $\begin{array}{l}-0.132 \\
{[0.151]}\end{array}$ \\
\hline Leverage & $\begin{array}{l}-0.148 \\
{[0.101]}\end{array}$ & $\begin{array}{l}-0.142 \\
{[0.101]}\end{array}$ & $\begin{array}{c}0.176^{* * *} \\
{[0.041]}\end{array}$ & $\begin{array}{c}0.170^{* * *} \\
{[0.041]}\end{array}$ \\
\hline Tangibility & $\begin{array}{c}-0.464^{*} \\
{[0.249]}\end{array}$ & $\begin{array}{c}-0.502^{* *} \\
{[0.250]}\end{array}$ & $\begin{array}{c}0.041 \\
{[0.096]}\end{array}$ & $\begin{array}{c}0.042 \\
{[0.096]}\end{array}$ \\
\hline Adjusted $R^{2}$ & 0.175 & 0.104 & 0.169 & 0.105 \\
\hline
\end{tabular}




\section{Appendix 1: Variable definitions, sources, and mean and median values}

This table presents definition and source for all variables used in the study. The sample is 342 large US public firms filing for bankruptcy in 1996-2007 and resolved by the end of 2010. The mean and median values are from the last fiscal year before Chapter 11 filing and in constant 2009 US dollars. Potentially unbounded variables are winsorized at the $1 \%$ and $99 \%$ level. The table uses "BRD" for Bankruptcy Research Database and "BD" for BankrutpcyData.com. Bankruptcy plans are obtained from BD, $8 \mathrm{Ks}$, and various US Bankruptcy Courts. The 10Ks, 8Ks, and proxy statements are from EDGAR and the 13Fs from Thompson Reuters Ownership Database. The mean and median values for Panels E and F are based on all departed and newly hired CEOs in the sample, respectively.

\begin{tabular}{|c|c|c|c|c|}
\hline Variable name & Variable definition & Source & Mean & Median \\
\hline \multicolumn{5}{|l|}{ A. Firm characteristics } \\
\hline Assets & Book value of total assets (in $\$$ millions). & BRD, BD, Compustat & 3,278 & 798 \\
\hline Sales & Total sales (in $\$$ millions). & BRD, BD, Compustat & 2,912 & 739 \\
\hline Size & Logarithm of total sales (in $\$$ millions). & BRD, BD, Compustat & & \\
\hline $\mathrm{ROA}$ & Ratio of EBITDA to book value of total assets. & Compustat, $10 \mathrm{Ks}$ & 0.009 & 0.039 \\
\hline Leverage & Ratio of total liabilities to book value of total assets. & Compustat, $10 \mathrm{Ks}$ & 1.044 & 0.953 \\
\hline Cash & Ratio of cash and short-term investments to book value of total assets. & Compustat, $10 \mathrm{Ks}$ & 0.069 & 0.030 \\
\hline Tangibility & Ratio of net PP\&E to book value of total assets. & Compustat, $10 \mathrm{Ks}$ & 0.377 & 0.354 \\
\hline Interest coverage & Ratio of EBITDA to interest expense. & Compustat, $10 \mathrm{Ks}$ & 0.131 & 0.617 \\
\hline Institution ownership (\%) & Percent shares owned by institutions. & $13 \mathrm{Fs}$ & 24.4 & 17.6 \\
\hline Bank loan/liabilities & Ratio of the face value of bank loans to total liabilities. & $\begin{array}{l}\text { Bankruptcy Plans, Compus- } \\
\text { tat, CapIQ }\end{array}$ & 0.264 & 0.208 \\
\hline Bonds/liabilities & Ratio of the face value of bonds outstanding to total liabilities. & $\begin{array}{l}\text { Bankruptcy Plans, Compus- } \\
\text { tat, CapIQ }\end{array}$ & 0.393 & 0.381 \\
\hline Nondebt/liabilities & Ratio of total liabilities less bank loans and bonds to total liabilities. & $\begin{array}{l}\text { Bankruptcy Plans, Compus- } \\
\text { tat, CapIQ }\end{array}$ & 0.346 & 0.284 \\
\hline \multicolumn{5}{|c|}{ B. Bankruptcy characteristics } \\
\hline Prepack & $\begin{array}{l}\text { Indicator variable taking the value of one if the bankruptcy is prepackaged } \\
\text { or pre-negotiated. }\end{array}$ & BRD, BD, Bankruptcy Plans & 0.304 & 0 \\
\hline DIP & $\begin{array}{l}\text { Indicator variable taking the value of one if debtor-in-possession (DIP) fi- } \\
\text { nancing is obtained from prepetition lenders. }\end{array}$ & $\begin{array}{l}\text { BRD, BD, Bankruptcy } \\
\text { Plans, Factiva, LexisNexis }\end{array}$ & 0.515 & 1 \\
\hline Emergence & $\begin{array}{l}\text { Indicator variable taking the value of one if the firm subsequently emerges } \\
\text { from bankruptcy. }\end{array}$ & BRD, BD, Bankruptcy Plans & 0.640 & 1 \\
\hline Acquisition & $\begin{array}{l}\text { Indicator variable taking the value of one if the firm is acquired in } \\
\text { bankruptcy. }\end{array}$ & BRD, BD, Bankruptcy Plans & 0.102 & 0 \\
\hline
\end{tabular}


Appendix 1 continued from previous page

\begin{tabular}{|c|c|c|c|c|c|c|}
\hline Variable name & Variable definition & \multicolumn{3}{|l|}{ Source } & Mean & Median \\
\hline Liquidation & $\begin{array}{l}\text { Indicator variable taking the value of one if the firm is liquidated or con- } \\
\text { verted into Chapter } 7 \text { in bankruptcy. }\end{array}$ & \multicolumn{3}{|c|}{ BRD, BD, Bankruptcy Plans } & 0.257 & 0 \\
\hline Duration & $\begin{array}{l}\text { Number of months in bankruptcy, from the date of filing to the date of plan } \\
\text { confirmation. }\end{array}$ & \multicolumn{3}{|c|}{ BRD, BD, Bankruptcy Plans } & 16.562 & 12.650 \\
\hline Recovery & $\begin{array}{l}\text { Creditor recovery in bankruptcy as a fraction of the total face value of their } \\
\text { claims. }\end{array}$ & \multicolumn{3}{|c|}{ BRD, BD, Bankruptcy Plans } & 0.532 & 0.521 \\
\hline \multicolumn{7}{|c|}{ C. CEO characteristics } \\
\hline Tenure & CEO tenure with the firm in years. & $\begin{array}{l}\text { Execcomp, } \\
\text { Statements }\end{array}$ & $10 \mathrm{Ks}$ & Proxy & 4.840 & 3 \\
\hline Age & $\mathrm{CEO}$ age in years. & $\begin{array}{l}\text { Execcomp, } \\
\text { Statements }\end{array}$ & $10 \mathrm{Ks}$ & Proxy & 52.839 & 53 \\
\hline Chairman & $\begin{array}{l}\text { Indicator variable taking the value of one if the CEO is chairman of the } \\
\text { board. }\end{array}$ & $\begin{array}{l}\text { Execcomp, } \\
\text { Statements }\end{array}$ & $10 \mathrm{Ks}$ & Proxy & 0.579 & 1 \\
\hline Turnover & $\begin{array}{l}\text { Indicator variable taking the value of one if the CEO with the firm is ter- } \\
\text { minated. }\end{array}$ & $\begin{array}{l}\text { Execcomp, } \\
\text { Statements, }\end{array}$ & $\begin{array}{l}10 \mathrm{Ks}, \\
3 \mathrm{D}, \mathrm{Fac}\end{array}$ & $\begin{array}{l}\text { Proxy } \\
\text { iva }\end{array}$ & 0.257 & 0 \\
\hline Ownpct & Percent of common shares owned by the CEO. & $\begin{array}{l}\text { Execcomp, } \\
\text { Statements }\end{array}$ & $10 \mathrm{Ks}$ & Proxy & 6.898 & 1.495 \\
\hline ValEquity & $\begin{array}{l}\text { Total value of shares and unexercised (unexercisable and exercisable) options } \\
\text { (in } \$ \text { millions), following Core and Guay (1999). }\end{array}$ & $\begin{array}{l}\text { Execcomp, } \\
\text { Statements, }\end{array}$ & $\begin{array}{l}\text { 10Ks, } \\
\text { CRSP }\end{array}$ & Proxy & 22.770 & 2.223 \\
\hline \multicolumn{7}{|c|}{ D. CEO compensation characteristics } \\
\hline Salary & CEO salary (in $\$$ thousands). & $\begin{array}{l}\text { Execcomp, } \\
\text { Statements }\end{array}$ & $10 \mathrm{Ks}$ & Proxy & 583 & 534 \\
\hline Bonus & Cash bonus plus non-equity long-term incentives (in $\$$ thousands). & $\begin{array}{l}\text { Execcomp, } \\
\text { Statements }\end{array}$ & $10 \mathrm{Ks}$ & Proxy & 300 & 0 \\
\hline Grants & $\begin{array}{l}\text { Total value of restricted stock granted and new stock options (Black-Scholes } \\
\text { value) granted (in } \$ \text { thousands). }\end{array}$ & $\begin{array}{l}\text { Execcomp, } \\
\text { Statements }\end{array}$ & $10 \mathrm{Ks}$ & Proxy & 1,209 & 23 \\
\hline SalaryBonus & Salary and bonus (in $\$$ thousands). & $\begin{array}{l}\text { Execcomp, } \\
\text { Statements }\end{array}$ & $10 \mathrm{Ks}$ & Proxy & 883 & 656 \\
\hline Totalpay & Sum of salary, bonus and grants (in $\$$ thousands). & $\begin{array}{l}\text { Execcomp, } \\
\text { Statements }\end{array}$ & $10 \mathrm{Ks}$ & Proxy & 2,092 & 866 \\
\hline CashPay & Ratio of salary and bonus to Totalpay. & $\begin{array}{l}\text { Execcomp, } \\
\text { Statements }\end{array}$ & $10 \mathrm{Ks}$ & Proxy & 0.722 & 0.923 \\
\hline
\end{tabular}


Appendix 1 continued from previous page

\begin{tabular}{llcl}
\hline Variable name & Variable definition & Mean & Median
\end{tabular}

\section{E. Departed CEOs}

Turnover reasons

Forced

Severance

Contractual severance

Discretional severance

Post-departure careers

\section{F. Newly Hired CEOs}

External

Specialist

CEObefore

NewCEOPublic
Reasons of turnover include (1) resigned for personal reasons, (2) pursue other interest, (3) pressured by board, shareholders, or creditors, (4) performance related, (5) liquidation or acquisition, (6) retirement or normal succession, (7) death or illness, (8) finishing transition period, (9) no reason given.

Indicator variable taking the value of one if turnover reasons are (3) and (4) in the above definition; the turnover reasons are (1), (2), and (9) but the CEO is not employed by another company as a CEO immediately after turnover; the turnover reason is (5) and the incumbent CEO departs prior to age 60 .

Indicator variable taking the value of one if separation pay if provided to the departing CEO.

Separation pay based on contract (in $\$$ thousands), conditional on receiving severance.

Discretional separation pay including lump-sum cash pay, loan forgiveness, adjustment to pension benefits, consulting contract, and equity incentives, conditional on receiving severance.

The employment types of departed CEOs, including (1) stay as chairman

(2) retaining honorary position, (3) CEO at a public company, (4) CEO at a private company, (5) non-CEO executive (e.g. CFO, COO, VP, manager etc.) at a public company, (6) non-CEO executive (e.g. CFO, COO, VP, manager etc.) at a private company, (7) consultant or politician, (8) selfemployed, (9) no new employment (e.g. retired, death, studying etc.).

Indicator variable taking the value of one if the new $\mathrm{CEO}$ is hired from outside the firm.

Indicator variable taking the value of one if a the new CEO is a turnaround specialist.

Indicator variable taking the value of one if the externally hired CEO holds CEO position immediately before hiring.

Indicator variable taking the value of one if the externally hired CEO works at a public firm immediately before hiring.
10Ks, Proxy Statements,

Factiva

10Ks, Proxy Statements, $0.488 \quad 0$

Factiva

10Ks, Proxy Statements, 0.277

Factiva

10Ks, Proxy Statements, 1,373

Factiva

10Ks, Proxy Statements, 1,460

Factiva

10Ks, Proxy Statements,

Factiva, S\&P Register of

Corporations, Directors and

Executives, Marquis Who's

Who in Finance and Business, Forbes, Businessweek, and LinkedIn.

10Ks, Proxy Statements, 0.571 BD, Factiva

10Ks, Proxy Statements, 0.181

BD, Factiva

10Ks, Proxy Statements, 0.413

BD, Factiva.

10Ks, Proxy Statements, $0.409 \quad 0$

BD, Factiva 
Appendix 1 continued from previous page

\begin{tabular}{|c|c|c|c|c|c|}
\hline Variable name & Variable definition & Source & & Mean & Median \\
\hline NewCEOIndMatch & $\begin{array}{l}\text { Indicator variable taking the value of one if the externally hired CEO works } \\
\text { at a firm that is in the same industry (two-digit SIC) as the new firm } \\
\text { immediately before hiring. }\end{array}$ & $\begin{array}{l}\text { 10Ks, Proxy } \\
\text { BD, Factiva }\end{array}$ & Statements, & 0.293 & 0 \\
\hline
\end{tabular}

